\title{
What moves stock prices around credit rating changes?
}

\author{
Omri Even-Tov ${ }^{1} \cdot$ Naim Bugra Ozel ${ }^{2,3}$
}

Accepted: 9 December 2020 / Published online: 7 January 2021

(C) The Author(s), under exclusive licence to Springer Science+Business Media, LLC part of Springer Nature 2021

\begin{abstract}
Using monthly and multi-day return windows, research shows that credit rating downgrades often reveal new information and lead to significant stock price reactions but that upgrades do not. Using intraday data, we revisit these findings and extend them by examining the possibility of informed trading ahead of the announcement of credit rating changes. Credit rating agencies delay public announcements of rating changes to provide issuers with time to review and respond to rating reports, which opens the door for informed trading in advance of credit rating changes. Using data on rating changes from S\&P, Moody's, and Fitch, we find a more modest price reaction to rating downgrades than documented elsewhere and show that stock prices respond to changes in long-term issuer ratings but not to changes in ratings of a single instrument or a subset of instruments. Most interestingly, we find that prices start moving before a downgrade announcement, controlling for other news and investor anticipation. These pre-announcement movements are concentrated among observations where credit analysts are motivated to disclose private information to advance their careers. The beneficiaries of these disclosures appear to be institutional investors.
\end{abstract}

Keywords Credit ratings · Intraday timing · Corporate news · Investor anticipation · Informed trading $\cdot$ Institutional trading

JEL classification $\mathrm{D} 82 \cdot \mathrm{G} 12 \cdot \mathrm{G} 14 \cdot \mathrm{G} 24$

Naim Bugra Ozel

naim.ozel@utdallas.edu

1 Haas School of Business, University of California, Berkeley, Berkeley, CA, USA

2 N. Jindal School of Management, University of Texas at Dallas, Richardson, TX, USA

3 The Wharton School, University of Pennsylvania (Visiting), 3620 Locust Walk, Suite 1314, Philadelphia, PA 19104, USA 


\section{Introduction}

An extensive literature has examined stock price reactions to credit rating announcements (e.g., Griffin and Sanvicente 1982; Holthausen and Leftwich 1986; Hand et al. 1992; Goh and Ederington 1993; Jorion et al. 2005). This literature has used monthly or multi-day announcement windows in the analyses. In this paper, we use intraday data to explore the impact of credit rating changes on stock prices. Our analysis uses data from the three largest rating agencies-S\&P, Moody's, and Fitch - and examines rating changes at both the issuer and instrument level.

We examine two main issues. The first is the stock price reaction to credit rating changes. Our intraday data allows us to narrow the window around which we calculate returns. This alleviates the concern that the observed price reaction to rating changes may be over- or understated due to other factors, such as unrelated news (Griffin and Sanvicente 1982; Holthausen and Leftwich 1986). The second issue we investigate is whether informed trading occurs before the announcement of rating changes. This sort of trading can arise because of the delay between a rating agency's internal decision to change a rating and the public announcement of the change (a period of up to $48 \mathrm{~h}$ ). Among those who might trade during this time are the credit analysts, investors with privileged access to rating agency personnel, and issuers' insiders, who receive advance notification of rating changes. ${ }^{1}$ Employing intraday data helps detect informed trading since the public announcement of a rating change sometimes happens on the same day as the rating change decision. Our results can clarify credit ratings' significance to investors and researchers and inform rating agencies and regulators about deficiencies in rating dissemination.

Our sample consists of credit rating change announcements by S\&P, Moody's, and Fitch between January 2001 and June 2017. Examining all three major rating agencies enables comparisons across agencies and rules out the possibility that idiosyncrasies of one agency drive our results. In contrast to other important corporate announcements (e.g., earnings announcements), most rating change announcements occur during trading hours (64\%), and only $4 \%$ happen before trading hours. Even so, we find notable timing differences across the three agencies. We also find timing differences between upgrades and downgrades, which may contribute to the asymmetrical price reactions. This difference in timing supports Griffin and Sanvicente's (1982) recommendation that intraday analysis should be used to estimate price adjustments to credit rating changes more accurately.

We investigate returns over different windows, starting at 1950 trading minutes before the announcement and ending at 120 trading minutes afterward. ${ }^{2}$ In general, we find that stock price reactions to S\&P's and Moody's announcements are stronger than those to Fitch's. We also confirm findings that stock returns around rating change announcements are statistically and economically significant and that downgrades elicit

\footnotetext{
${ }^{1}$ An SEC report on the role and function of credit rating agencies (SEC 2003) says: "Some [hearing participants] expressed concern that [...] the informal verbal contacts between subscribers and rating agency analysts increased the risk of improper disclosure of confidential information provided by the issuer. Others believe these contacts could inappropriately signal to subscribers information about upcoming ratings changes (and their associated market impact)."

${ }^{2}$ We account for each overnight period (i.e., the period between 16:00 of day t-1 and 9:30 of day t) as one trading minute.
} 
stronger responses than upgrades. More importantly, we show that the average returns over the two hours following the announcement are small, ranging from $-0.1 \%$ to $-0.9 \%$ for downgrades and from $0.1 \%$ to $0.2 \%$ for upgrades, relative to the figures reported in studies using multi-day announcement windows. ${ }^{3}$ We attribute this discrepancy to the statistically and economically significant returns in the direction of upcoming rating changes (up to $-1.5 \%$ for downgrades and up to $0.4 \%$ for upgrades) over the 780 trading minutes (48 trading hours) before the announcement, which we refer to as the pre-announcement period. Additionally, we find significant returns over the 1170 min (72 trading hours) ending 780 trading minutes before the announcement, which we refer to as the leading period.

One of the factors that may explain this pattern of returns is other information that comes out in advance of rating changes. When multi-day windows are used to measure returns, the market impact of this information may be obscured (as acknowledged, for example, by Hand et al. (1992), Holthausen and Leftwich (1986), and Jorion et al. (2005)). We find that most rating change announcements $(86 \%)$ across the three agencies either cite recent corporate news or are issued within five days of such an event. Once we remove these contaminated observations, there is no longer a significant price movement over the leading period. Pre-announcement and announcement returns remain significant for long-term issuer ratings (hereafter issuer ratings), which reflect agencies' opinion about an issuer's overall creditworthiness. In contrast, they are not significant for instrument changes unaccompanied by a change in issuer ratings. In additional cross-sectional tests, we consider various factors, including rating class, business cycle phase, watch or outlook status, and remaining maturity of instruments, which may influence investors' reaction to rating changes, and continue to find that our results are concentrated among issuer ratings regardless of the factor. Therefore the remainder of our analysis focuses on issuer rating changes only.

We next examine whether investor anticipation of credit rating changes can explain pre-announcement-period return patterns. Studies suggest that rating changes lag behind changes in operations and financials by several weeks and that investors likely anticipate the rating changes (Pinches and Singleton 1978; Beaver et al. 2006; Cheng and Neamtiu 2009). We proxy for investor anticipation by using long-term stock returns, credit default swap (CDS) spread changes, and bond returns. Our analysis shows that the combination of corporate news and investor anticipation explains preannouncement period returns for upgrades. However, even after accounting for these factors, we continue to observe significant pre-announcement period returns for downgrades.

A third potential explanation is informed trading in advance of downgrade announcements. Consistent with informed trading, significant pre-announcement returns

\footnotetext{
${ }^{3}$ For example, for downgrades, Holthausen and Leftwich (1986) find an average announcement return of $-2.66 \%$. Chava et al. (2012) document a mean return of $-4.31 \%$ using a two-day announcement window. Jorion et al. (2005) find an average announcement return of $-4.57 \%(-6.93 \%)$ for pre- (post-) Reg FD periods using a three-day window.
} 
are observed during the $48 \mathrm{~h}$ before the rating change announcement, when both agency analysts and issuers' insiders are likely privy to the rating change. ${ }^{4}$ Second, trading on private information can be costly, and larger announcement returns for downgrades suggest more substantial economic benefits from trading ahead of them. SEC Rule 10b5-1 prohibits trading based on nonpublic material information. A violation of this rule can lead to financial penalties, jail time, criminal and civil penalties, and loss of professional license. ${ }^{5}$ Additional costs are imposed for violation of credit rating agencies' internal policies. ${ }^{6}$ Therefore it is plausible to expect higher rates of informed trading before downgrades.

We first examine whether issuers' insiders benefit from their foreknowledge of rating changes by trading or delaying their trades. Prior research points to insider trading in related contexts. Seyhun and Bradley (1997) and Griffin et al. (2014) document insider sales ahead of bankruptcies and debt covenant violations, respectively. We show that insiders significantly reduce trading ahead of credit rating change announcements, especially before downgrades. Our evidence shows that insiders avoid trading, likely due to fear of regulatory or investor scrutiny, rather than exploiting their foreknowledge of rating changes. Therefore, while our results indicate that insiders are aware of the rating change before its announcement, their awareness cannot explain the returns we identify during the pre-announcement period.

Next, we explore whether credit analysts benefit from their knowledge of upcoming rating changes. Our sample includes at least one credit analyst who was prosecuted for insider trading. However, data on credit analysts' trades is not available, so, for our analysis, we turn to career-related incentives that may motivate analysts to leak information. Research indicates that these incentives exert a measurable effect on the accuracy of rating decisions concerning analysts' future employers (e.g., Cornaggia et al. 2016; Jiang et al. 2018; Kempf 2020). In the same vein, an analyst may disclose information to investors in the asset or portfolio management industry to secure a job in that sector. Therefore we use credit analysts' first position after S\&P, Moody's, or Fitch as a proxy for their incentives to share information with asset or portfolio management

\footnotetext{
${ }^{4}$ Details regarding the release schedule that we describe are drawn from official documentation posted on the three credit rating agencies' websites. An upcoming rating announcement is communicated privately to the issuer by the rating agency after the decision has been approved. This notification is intended to verify accuracy with the issuer and to eliminate risk of unintentional disclosure of confidential information in the ratings report.

${ }^{5}$ Identifying and verifying that a specific trade is based on nonpublic material information is difficult. Investigators must show that a trade is conducted based on confidential information about the upcoming rating change rather than as a response to the event(s) preceding the rating change. If the informed trader is a third party seemingly unrelated to the information source or if the immediate benefits to the person suspected of disclosing the information are unclear, this task can be challenging.

${ }^{6}$ There are two regulations that require rating agencies to maintain policies and procedures to prevent disclosure to third parties of pending rating actions and confidential information regarding issuers: Rule $17 \mathrm{~g}-4$ and the SEC Investment Advisers Act of 1940. Consistent with these regulations, rating agencies prohibit or restrict analysts and rating committee members from trading or holding securities of the companies that belong to their employees' areas of practice. Violation of these policies may lead to negative outcomes for rating agency employees, ranging from a written warning to loss of employment and reputational damage. These two regulations do not impose any penalties on the rating agency itself for violations of its internal policies, unless they are proven to result in violations of a federal law. In fact, the SEC cited significant problems with the enforcement of agencies' internal policies and even found that one large agency's procedures allowed employees to selectively disseminate information about pending rating actions (SEC 2011).
} 
firms. In doing so, we find significantly stronger pre-announcement period returns for downgrades among analysts from S\&P and Moody's with career-related incentives. We do not find significant evidence for analysts from Fitch, which may stem partially from the relatively small sample size.

If this sort of information sharing with institutional investors drives the preannouncement period returns, we would expect to observe more trading by institutional investors ahead of credit rating changes. We follow Boehmer et al. (2019) and Farrell et al. (2018) and identify retail and institutional investors' buy and sell orders using the TAQ database. We find that institutional investors are net sellers ahead of downgrade announcements and that their trade volume, relative to that of retail investors, increases ahead of downgrades but not upgrades. These results are consistent with some institutional investors gaining an information advantage through their links to rating analysts. We caveat that, due to data requirements, the sample size used for this analysis is significantly smaller, which might limit the generalizability of our findings to all firms.

Our study comprehensively analyzes the information content of credit rating changes, where we not only confirm existing evidence but also uncover novel results. Among the first studies to examine the stock price reaction to rating changes were those by Pinches and Singleton (1978) and Griffin and Sanvicente (1982). Following that work, Holthausen and Leftwich (1986), Hand et al. (1992), and Goh and Ederington (1993) documented an asymmetrical response for downgrades and upgrades and explored whether concurrent corporate news partially drove this. Jorion et al. (2005) found a stronger price reaction to rating changes after the adoption of Regulation Fair Disclosure (Reg FD) in 2000, which granted issuers an exemption for disclosure of material nonpublic information to credit rating agencies. ${ }^{7}$ We add to this literature in several ways. First, we provide initial evidence on the timing of credit rating changes. We show that most of these changes are announced during trading hours but that timing varies across rating agencies and between downgrades and upgrades. ${ }^{8}$ Second, using a narrow window around rating change announcements, our results indicate that (i) stronger announcement returns to downgrades are likely driven by higher information content, rather than by other factors; and (ii) price reactions to rating change announcements are smaller than those reported in the literature. Finally, whereas prior research has focused on a pooled sample of rating changes or issuer rating changes only, we examine issuer and instrument rating changes separately. This distinction matters because stock prices typically do not react to changes in instrument ratings.

Our study also provides evidence of informed trading ahead of credit rating changes and highlights a possible channel through which some institutional investors may gain an information advantage over other investors. This addresses a potential concern of

\footnotetext{
${ }^{7}$ Other studies explore the reaction of CDS spreads to credit rating change announcements (e.g., Chava et al. 2012; Hull et al. 2004; Norden and Weber 2004; Norden 2017). In addition to our examination of a different security and use of a different sample composition, we focus on the drivers of price movements ahead of credit rating changes, whereas prior studies primarily focus on the predictive power of long-term changes in CDS spreads. None of the aforementioned studies investigate whether observed returns are driven by corporate news events, investor anticipation, or information leakage.

${ }^{8}$ In a concurrent study, Kraft et al. (2020) examine intraday timing of S\&P's credit rating change announcements. They focus on the determinants of intraday timing, whereas we focus on the price reactions to rating changes.
} 
investors, such as asset managers whose trades may be front-run by parties with foreknowledge of rating changes, and the Securities and Exchange Commission (SEC), which aims to ensure fair disclosure of rating information to all market participants. ${ }^{9}$ Our evidence underscores these concerns. In this respect, we add to the growing body of research on information leakage ahead of important corporate news, such as equity analysts' recommendations (Irvine et al. 2007; Christophe et al. 2010; Griffin et al. 2012) and earnings announcements (Christophe et al. 2004; Bushman et al. 2010). ${ }^{10}$ We provide evidence of informed trading by some investors, possibly using information learned from rating agency analysts. Credit rating agencies differ from brokerages in several ways. Brokerages benefit from employees leaking information by receiving additional business from preferred clients. In contrast, no such benefits accrue to rating agencies, and thus they are less likely to ignore information leakage. Moreover, the SEC allows issuers to disclose confidential information to rating agencies but not to brokerages. Therefore information leakage in this setting is of potentially greater concern for investors, issuers, and regulators.

Our work also relates to studies that document abnormal insider trading before bankruptcies and debt covenant violations (Seyhun and Bradley 1997; Beneish et al. 2011; Griffin et al. 2014). Our findings differ in at least two ways. First, whereas these papers find that issuers' insiders benefit from informed trading, we find that the beneficiaries are rating analysts and institutional investors. Second, these studies document insider trading over horizons of months and even years. In contrast, we document informed trading over two days, which allows us to better abstract from general market movements and investor anticipation.

Finally, our study relates to the literature exploring the effect of credit analysts' career incentives on credit rating quality. Studies find that credit analysts issue more favorable ratings on securities issued or underwritten by their future employers (Cornaggia et al. 2016; Jiang et al. 2018; Kempf 2020). Relatedly, Kempf and Tsoutsoura (2019) show that credit analysts affiliated with the U.S. president's political party are more likely to assign higher corporate credit ratings than unaffiliated analysts. Our study adds to this literature by showing that analysts' professional motivations can affect not only the quality but also the dissemination of ratings information. In doing so, it exposes deficiencies in credit rating agencies' practices, which should raise concern among issuers who share private information (such as about future mergers and acquisitions) with the agencies. $^{11}$

\footnotetext{
${ }^{9}$ See SEC (2000).

${ }^{10}$ Relatedly, Michaelides et al. (2015) find that, in corrupt economies, stock markets move at least two weeks ahead of sovereign debt rating changes. Aside from institutional and regulatory differences between the two settings, Michaelides et al. do not test for investor anticipation or for the presence of other economic news events (except those that cite a rating) as possible explanations.

${ }^{11}$ For example, in 2018, a credit analyst working at S\&P and two friends were criminally charged with insider trading regarding the impending transaction between two paint makers, after the analyst had learned about it in confidential memos at work (Stempel 2018)
} 


\section{Data and sample selection}

We obtain information on credit rating changes for the three rating agencies from multiple sources. ${ }^{12}$ Our data on S\&P's credit rating changes come from Capital IQS\&P Credit Ratings Database, a comprehensive source of S\&P's rating information that includes details about the issuer and issues and the time and date of the rating change announcement. Our data on credit rating changes for Moody's and Fitch are drawn from the Mergent Fixed Income Securities database (FISD), which includes the date but not the time of rating change announcements. Both databases begin coverage in mid-1995. Given evidence that Reg FD affected the informativeness of credit rating changes (Jorion et al. 2005) and that the implementation of decimal pricing by all major exchanges by early 2001 altered stock price responses to corporate events (e.g., Graham et al. 2003), we begin our sample in January 2001 and end in June 2017.

Our sample consists of all credit rating changes that satisfy the following criteria: (i) announced during trading days, (ii) not preceded by another rating action in the previous 15 days, (iii) issued without any qualifiers, and (iv) (for instrument ratings only) an original maturity of at least 18 months. We identify historical tickers for observations in Mergent FISD by linking this database to Compustat and CRSP using issuer CUSIP codes. For Capital IQ-S\&P Credit Ratings Database, we use GVKEY as the linking variable. We require that each observation in our sample has a nonmissing and valid stock ticker and rating change date.

Our intraday stock return data comes from the TAQ database. We apply the common filters used in the market microstructure literature to calculate intraday stock returns. Specifically, we exclude those trades (i) conducted outside of regular trading hours, (ii) with Trade Correction Indicator field entries other than " 00 ," and (iii) with a Sale Condition field value in the set $\{\mathrm{B}, \mathrm{G}, \mathrm{J}, \mathrm{K}, \mathrm{L}, \mathrm{O}, \mathrm{T}, \mathrm{W}, \mathrm{Z}\} .{ }^{13}$ To minimize the impact of stale prices and microstructure effects, we remove stocks if their price drops below $\$ 1$ or if they trade less than once every five minutes on average during the event window around rating announcements, which is the $[-1950,120]$ trading-minute interval where zero is the minute of the rating change announcement. Finally, to reduce the effect of outliers, we exclude observations that are in the top or bottom one percentile of total stock return over the event window. This selection process yields samples of 4723, 3388, and 1172 credit rating changes for S\&P, Moody's, and Fitch, respectively.

\footnotetext{
${ }^{12}$ Among the 10 nationally recognized statistical rating organizations (NRSROs), the three largest agencies are S\&P, Moody's, and Fitch. As of 2016, these three held a collective global market share of roughly $95 \%$, with S\&P and Moody's holding approximately $40 \%$ each and Fitch around $15 \%$.

13 According to the TAQ User's Guide, a Trade Correction Indicator value of " 00 " signifies a regular trade that was not corrected, changed, or canceled. A sale condition value of B signifies an aggregate of two or more regular trades executed at the same time. G signifies a trade not reported within $90 \mathrm{~s}$ of execution. J signifies a trade reported as having been executed as a block position. $\mathrm{K}$ signifies a specialist trade. $\mathrm{L}, \mathrm{O}$, and $\mathrm{Z}$ signify transactions reported to the tape at a later time. T signifies a trade executed outside market hours. W signifies a trade where the price reported is an average of the prices of transactions executed during all or any portion of the trading day.
} 
We use the timestamps reported in the Capital IQ-S\&P Credit Ratings Database to identify the time of S\&P's rating changes. The Mergent FISD database does not provide timestamps for Moody's and Fitch. Therefore we locate the press release or first newswire article about the rating change and manually extract the timestamp. ${ }^{14}$ Appendix Table 10 reports the intraday distribution of rating change announcements in our sample. The majority of rating changes across all three agencies (64\%) are announced during trading hours (9:30-16:00 EST). Announcements before trading hours are uncommon, and thus daily stock returns for the day of rating change announcements could include price movements ahead of the changes themselves. This could be more acute for Moody's, because it is more (less) likely to announce ratings after (before) trading hours. Additionally, all three agencies are more likely to announce downgrades after trading hours than upgrades, suggesting that Kraft et al.'s (2020) findings regarding the relative timing of S\&P's upgrades and downgrades extend to other agencies.

In Table 1, we present descriptive statistics for the three agencies. Panel A provides summary statistics for each sample. We measure credit ratings over a cardinal scale ( 1 = AAA, 2 = AA+, and so on). The mean and median credit ratings following a rating change (Rating) are two notches below the investment-grade cutoff (i.e., BBB- / Baa3) for S\&P and Moody's. Fitch assigns higher ratings on average, as its mean and median ratings are at or one notch above the investment-grade cutoff, respectively. S\&P and Moody's have more downgrades than upgrades (Upgrade) in our sample, whereas Fitch has approximately an equal number of both. We present stock returns for four windows: the full event window (FRet), $2070 \mathrm{~min}$, starting $1950 \mathrm{~min}$ before a rating change announcement; the leading period (LRet), $1170 \mathrm{~min}$, starting $1950 \mathrm{~min}$ before a rating change announcement; the pre-announcement period (PreRet), $780 \mathrm{~min}$, starting 781 min before a rating change announcement; and the announcement period (AnnRet), $121 \mathrm{~min}$, starting one minute before a rating change announcement. ${ }^{15}$ Given that each trading day consists of 390 trading minutes, our full event window begins five trading days before a rating change announcement. The mean stock returns over the leading period (LRet), the pre-announcement period (PreRet), and the announcement period (AnnRet) are all negative and are around 50 (10) basis points for S\&P (Moody's and Fitch). The medians are all approximately zero.

Panel B of Table 1 presents the distribution of rating change announcements by year and rating agency. The frequency of rating changes is fairly stable over time, with more rating changes occurring from 2006 through 2010.

\footnotetext{
${ }^{14}$ For approximately $6 \%$ of the sample announcements, we cannot identify the exact timestamp. In order not to bias our estimates of pre-announcement returns in the direction of the rating change announcement, we assume that these announcements occur at the beginning of the trading day. Our inferences remain identical if we remove these observations from our sample.

${ }^{15}$ We designate the pre-announcement period as starting at the earliest time that internal decisions for a rating action are made by the rating agencies, according to their manuals, and ending one minute before the rating action's public announcement. The choice of windows for the leading and announcement periods are ad hoc. However, our inferences are unchanged when we use five- or 10-trading day windows for the leading period. We discuss the rating decision timeline in detail in Section 3.2.3.
} 
Table 1 Descriptive statistics for all rating change announcements

Panel A: Summary statistics

$$
\text { N Mean }
$$

Standard \& Poor's

Rating $\quad 4723$

Upgrade 4723

11.8

0.47

FRet 4723

LRet $\quad 4723$

PreRet 4723

AnnRet 4723

Moody's

Rating 3388

Upgrade $\quad 3388$

FRet 3388

LRet 3388

PreRet 3388

AnnRet 3388

$-0.016$

$-0.005$

$-0.006$

$-0.004$

Fitch

$\begin{array}{rcc}\text { Rating } & 1172 & 9.9 \\ \text { Upgrade } & 1172 & 0.51 \\ \text { FRet } & 1172 & -0.003 \\ \text { LRet } & 1172 & -0.002 \\ \text { PreRet } & 1172 & -0.001 \\ \text { AnnRet } & 1172 & 0.000\end{array}$

Panel B: Distribution over time

\begin{tabular}{|c|c|c|c|c|c|c|}
\hline & S\&P & & Moody's & & Fitch & \\
\hline Year & $\mathbf{N}$ & $\%$ & $\mathbf{N}$ & $\%$ & $\mathbf{N}$ & $\%$ \\
\hline 2001 & 239 & $5.1 \%$ & 151 & $4.5 \%$ & 38 & $3.2 \%$ \\
\hline 2002 & 256 & $5.4 \%$ & 164 & $4.8 \%$ & 56 & $4.8 \%$ \\
\hline 2003 & 292 & $6.2 \%$ & 168 & $5.0 \%$ & 54 & $4.6 \%$ \\
\hline 2004 & 222 & $4.7 \%$ & 164 & $4.8 \%$ & 58 & $5.0 \%$ \\
\hline 2005 & 294 & $6.2 \%$ & 187 & $5.5 \%$ & 56 & $4.8 \%$ \\
\hline 2006 & 300 & $6.4 \%$ & 342 & $10.1 \%$ & 85 & $7.3 \%$ \\
\hline 2007 & 314 & $6.7 \%$ & 217 & $6.4 \%$ & 98 & $8.4 \%$ \\
\hline 2008 & 413 & $8.7 \%$ & 216 & $6.4 \%$ & 66 & $5.6 \%$ \\
\hline 2009 & 349 & $7.4 \%$ & 256 & $7.6 \%$ & 52 & $4.4 \%$ \\
\hline 2010 & 275 & $5.8 \%$ & 186 & $5.5 \%$ & 119 & $10.2 \%$ \\
\hline 2011 & 283 & $6.0 \%$ & 167 & $4.9 \%$ & 79 & $6.7 \%$ \\
\hline 2012 & 251 & $5.3 \%$ & 197 & $5.8 \%$ & 93 & $7.9 \%$ \\
\hline 2013 & 246 & $5.2 \%$ & 164 & $4.8 \%$ & 61 & $5.2 \%$ \\
\hline 2014 & 276 & $5.8 \%$ & 214 & $6.3 \%$ & 84 & $7.2 \%$ \\
\hline 2015 & 281 & $6.0 \%$ & 183 & $5.4 \%$ & 48 & $4.1 \%$ \\
\hline 2016 & 319 & $6.8 \%$ & 240 & $7.1 \%$ & 72 & $6.1 \%$ \\
\hline 2017 & 113 & $2.4 \%$ & 172 & $5.1 \%$ & 53 & $4.5 \%$ \\
\hline
\end{tabular}

11.8

0.45

$-0.005$

$-0.001$

$-0.001$

$-0.003$

3.2

0.50

0.046

0.034

0.028

0.019

9.0
0.0
-0.033

$-0.033$

$-0.023$

$-0.018$

$-0.010$

8.0

0.0

$-0.026$

$-0.019$

$-0.015$

$-0.006$
$75 \%$

14.0

1.0

0.031

0.022

0.019

0.007

15.0

1.0

0.031

0.023

0.020

0.007

$-0.001$

12.0

1.0

0.023

0.016

0.015

0.006

$-0.001$ 
Table 1 (continued)

\begin{tabular}{lllllll}
\hline Total & 4723 & $100 \%$ & 3388 & $100 \%$ & 1172 & $100 \%$ \\
\hline
\end{tabular}

This table reports descriptive statistics for all rating change announcements in our sample. Variable definitions are available in Appendix Table 11

\section{Empirical analyses}

\subsection{Stock return patterns around rating change announcements}

We begin our analysis by examining the magnitude and statistical significance of intraday stock returns surrounding rating change announcements. Table 2 reports the returns over the full window (FRet) as well as separately over the leading period (LRet), the pre-announcement period (PreRet), and the announcement period (AnnRet).

Table 2 shows that downgrades elicit a stronger stock price reaction than upgrades across all three agencies. While this finding has been documented previously (e.g., Hand et al. 1992; Holthausen and Leftwich 1986; Jorion et al. 2005), the magnitude of the announcement reaction (i.e., AnnRet), especially for downgrades, appears small, relative to the estimates that range between $-1.5 \%$ and $-4.5 \%$ reported in the literature using multi-day returns. This apparent discrepancy likely stems from the significant portion of returns around rating changes realized before the announcements. Therefore the use of daily windows that incorporate pre-announcement periods likely overstate the actual magnitude.

Table 2 Stock returns around all rating change announcements

\begin{tabular}{|c|c|c|c|c|c|c|c|c|c|c|c|}
\hline \multirow[b]{2}{*}{ Downgrades } & \multirow[b]{2}{*}{$\mathrm{S} \& \mathrm{P}$} & \multirow[b]{2}{*}{ Mean } & \multirow{2}{*}{$\begin{array}{l}\mathrm{N} \\
2516\end{array}$} & \multicolumn{2}{|c|}{$\begin{array}{l}\text { Fret } \\
{[-1950,120]}\end{array}$} & \multicolumn{2}{|c|}{$\begin{array}{l}\text { LRet } \\
{[-1950,-781]}\end{array}$} & \multicolumn{2}{|c|}{$\begin{array}{l}\text { PreRet } \\
{[-780,-2]}\end{array}$} & \multicolumn{2}{|c|}{$\begin{array}{l}\text { AnnRet } \\
{[-1,120]}\end{array}$} \\
\hline & & & & -0.033 & $* * *$ & -0.010 & $* * *$ & -0.015 & $* * *$ & -0.009 & $* * *$ \\
\hline & & Median & 2516 & -0.011 & $* * *$ & -0.001 & $* * *$ & -0.004 & $* * *$ & -0.003 & $* * *$ \\
\hline & Moody's & Mean & 1868 & -0.015 & $* * *$ & -0.004 & $* *$ & -0.005 & $* * *$ & -0.006 & $* * *$ \\
\hline & & Median & 1868 & -0.004 & $* * *$ & -0.001 & $*$ & -0.001 & $*$ & -0.003 & $* * *$ \\
\hline & Fitch & Mean & 569 & -0.010 & $* * *$ & -0.005 & $* * *$ & -0.002 & & -0.002 & $* *$ \\
\hline & & Median & 569 & -0.006 & $* * *$ & -0.003 & $* * *$ & -0.001 & & -0.001 & $* *$ \\
\hline \multirow[t]{6}{*}{ Upgrades } & S\&P & Mean & 2207 & 0.005 & $* * *$ & -0.001 & & 0.004 & $* * *$ & 0.002 & $* * *$ \\
\hline & & Median & 2207 & 0.004 & $* * *$ & 0.000 & & 0.003 & $* * *$ & 0.001 & $* * *$ \\
\hline & Moody's & Mean & 1520 & 0.007 & $* * *$ & 0.002 & $*$ & 0.004 & $* * *$ & 0.001 & $* *$ \\
\hline & & Median & 1520 & 0.005 & $* * *$ & 0.002 & $* *$ & 0.003 & $* * *$ & 0.001 & $* * *$ \\
\hline & Fitch & Mean & 603 & 0.003 & * & 0.002 & $*$ & 0.000 & & 0.001 & $* *$ \\
\hline & & Median & 603 & 0.002 & * & 0.002 & $* *$ & 0.000 & & 0.001 & $* * *$ \\
\hline
\end{tabular}

This table presents mean and median returns around all credit rating change announcements in our sample. Returns reported are the cumulative stock returns for the full window and for the three sub-windows around the rating change announcement. Minute zero corresponds to the minute the rating agency announces a credit rating change. Variable definitions are available in Appendix Table $11 .^{* * *},{ }^{* *}$, and ${ }^{*}$ denote significance at the $1 \%, 5 \%$, and $10 \%$ levels for two-tailed t-tests (Wilcoxon tests for medians), respectively 
Over the full period (FRet), the average stock return is $-3.3 \%,-1.5 \%$, and $-1.0 \%$ for downgrades by S\&P, Moody's, and Fitch, respectively. For upgrades, the average return is $0.5 \%, 0.7 \%$, and $0.3 \%$ for S\&P, Moody's, and Fitch, respectively. All of these values are statistically significant. A relatively small portion of these returns is realized at the time of the announcement. The average announcement period returns (AnnRet) are $-0.9 \%,-0.6 \%$, and $-0.2 \%$ for downgrades and $0.2 \%, 0.1 \%$, and $0.1 \%$ for upgrades by S\&P, Moody's, and Fitch, respectively. Much of S\&P and Moody's returns over the full period are realized before announcements (PreRet) for both downgrades and upgrades, although the leading period returns (LRet) are also economically and statistically significant for downgrades. We find insignificant pre-announcement returns for both downgrades and upgrades for Fitch's rating changes.

\subsection{Possible explanations for stock price movements ahead of rating changes}

Our findings in Table 2 suggest stock price movements in the direction of the upcoming rating change, indicating that factors other than the rating announcement affect prices. We evaluate three possible explanations: additional corporate news, investor anticipation, and informed trading.

\subsubsection{The role of other corporate news events}

Rating decisions can follow corporate news events that affect an issuer's creditworthiness and stock prices. Holthausen and Leftwich (1986), Hand et al. (1992), and Jorion et al. (2005) note that corporate news can lead to price movements around credit rating changes and stipulate that the multi-day announcement window can contaminate the measurement of announcement period stock returns. Without intraday data on rating changes and stock returns, these studies conduct a separate analysis using a sample that excludes Wall Street Journal (WSJ) articles about the issuer around the time of rating changes. Such corporate news can lead to significant price reactions in the direction of the upcoming rating change.

We perform a three-step filtering to examine whether preceding corporate news drive the price patterns we observe ahead of rating change announcements. First, we use the full edition of the Ravenpack News Analytics database and Compustat Filings database and eliminate any observation for which there is at least one relevant news item or a SEC filing of 10-K, 10-Q, 20-F, or 8-K forms over the four trading days prior to the day of the rating change. ${ }^{16}$ Second, we search for each remaining observation on the Factiva database and exclude any observation for which we can identify a relevant news article over the four trading days prior to the rating change announcement. Finally, for the remaining observations, we read through S\&P, Moody's, and Fitch press releases and omit any observation linked to a specific event that occurred within

\footnotetext{
${ }^{16}$ For every news article that mentions a company, Ravenpack assigns a relevance score between 0 and 100 , where 0 refers to cases where the firm is only mentioned in passing and 100 to cases where the firm is the subject. Von Beschwitz et al. (2015) find no significant market reaction to news with a relevance score of less than 90 and strong reaction to news with a relevance score above 90 . Thus we consider articles with a relevance score of 90 or above as confounding. Our inferences are unchanged when we use 75 as the cutoff, although some of our findings become statistically significant at the $10 \%$ level rather than at the $5 \%$ or $1 \%$ level. The reduction in statistical significance levels is likely driven in part by the smaller sample size.
} 
the last four trading days. After applying these filters, our sample consists of 777 rating change announcements for S\&P, (412 downgrades and 365 upgrades), 402 for Moody's (198 downgrades and 204 upgrades), and 127 for Fitch (64 downgrades and 63 upgrades) that are not triggered by other news events. Thus, across the three agencies, $86 \%$ of the rating change announcements are preceded by news events that might precipitate a rating change. ${ }^{17}$ Appendix 2 provides four examples of rating change announcements in our sample after imposing these filters.

Table 3 displays summary statistics for the sample of rating changes that are not preceded by other news events. Relative to the full sample, the median ratings are approximately one notch lower and the percentage of upgrades is similar.

The prevalence of rating changes preceded by other news events in our sample is consistent with the supposition that other news can drive stock price movements around rating change announcements. To examine to what extent other corporate news does explain the patterns we observe in Table 2, in Fig. 1, we plot the cumulative stock returns around rating change announcements using only those observations that are not preceded by other news.

Figure 1 presents the mean cumulative returns (calculated as $\left(\mathrm{P}_{\mathrm{t}}-\mathrm{P}_{-1950}\right) / \mathrm{P}_{-1950}$, where $\mathrm{P}_{t}$ is the price at minute $t$ ) surrounding credit rating downgrades and upgrades not preceded by other news beginning 1950 trading minutes before the public announcement of a rating change and ending 390 trading minutes after. We account for each overnight period (i.e., the period between 16:00 of day t-1 and 9:30 of day t) as one trading minute.

Figure 1 shows that, when the rating announcements likely triggered by recent news are excluded, the average cumulative stock return fluctuates around zero for both upgrades and downgrades until about 780 trading minutes before the announcement. After this point, similar to the patterns exhibited in the full sample reported in Table 2, stock prices begin to decrease (increase) before downgrades (upgrades). These directional price movements persist until the time of announcement. Over these $780 \mathrm{~min}$, stock prices decline by over $1 \%(0.5 \%)$ before downgrades by S\&P (Moody's and Fitch) and increase by approximately $0.5 \%(0.2 \%)$ before upgrades by S\&P and Moody's (Fitch). The stock price reactions at the time of the announcement resemble those in the full sample.

Table 4 reports the results from analyses of the mean and median returns around rating change announcements that are not preceded by other corporate news. As shown in this table, the leading period returns are mostly statistically insignificant. However, both the mean and median returns during the pre-announcement period remain statistically and economically significant for downgrades and upgrades, except for upgrades by Fitch. For downgrades by S\&P, the mean (median) pre-announcement returns are $-1.2 \%(-0.4 \%)$, compared to $-1.5 \%(-0.4 \%)$ in the full sample. For downgrades by Moody's, the mean (median) pre-announcement returns are $-0.5 \%(-0.4 \%)$, compared to $-0.5 \%(-0.1 \%)$ in the full sample. For downgrades by Fitch, the mean (median) preannouncement returns are $-0.5 \%(-0.3 \%)$, compared to $-0.2 \%(-0.1 \%)$ in the full

\footnotetext{
${ }^{17}$ Our filtering is more comprehensive than that used elsewhere, both in terms of our news sources and window. For example, Holthausen and Leftwich (1986), Hand et al. (1992), Goh and Ederington (1993), Jorion et al. (2005), and May (2010) classify 45\%, 53\%, 30\%, 23\%, and 42\% of their samples as contaminated, respectively.
} 
Table 3 Summary statistics for rating changes without other news events

\begin{tabular}{|c|c|c|c|c|c|c|}
\hline & $\mathrm{N}$ & Mean & SD & $25 \%$ & $50 \%$ & $75 \%$ \\
\hline \multicolumn{7}{|c|}{ Standard \& Poor's } \\
\hline Rating & 777 & 12.1 & 3.2 & 10.0 & 13.0 & 15.0 \\
\hline Upgrade & 777 & 0.47 & 0.50 & 0.0 & 0.0 & 1.0 \\
\hline FRet & 777 & -0.007 & 0.064 & -0.037 & 0.000 & 0.030 \\
\hline LRet & 777 & 0.000 & 0.493 & -0.023 & 0.001 & 0.021 \\
\hline PreRet & 777 & 0.000 & 0.049 & -0.023 & 0.001 & 0.021 \\
\hline AnnRet & 777 & -0.002 & 0.023 & -0.009 & 0.000 & 0.007 \\
\hline \multicolumn{7}{|l|}{ Moody's } \\
\hline Rating & 402 & 12.3 & 3.6 & 10.0 & 13.0 & 15.0 \\
\hline Upgrade & 402 & 0.51 & 0.50 & 0.0 & 1.0 & 1.0 \\
\hline FRet & 402 & -0.004 & 0.056 & -0.028 & -0.002 & 0.022 \\
\hline LRet & 402 & 0.000 & 0.042 & -0.020 & 0.001 & 0.020 \\
\hline PreRet & 402 & 0.000 & 0.034 & -0.014 & 0.000 & 0.014 \\
\hline AnnRet & 402 & -0.004 & 0.020 & -0.009 & -0.001 & 0.006 \\
\hline \multicolumn{7}{|l|}{ Fitch } \\
\hline Rating & 127 & 10.1 & 2.8 & 8.0 & 10.0 & 12.0 \\
\hline Upgrade & 127 & 0.50 & 0.50 & 0.0 & 0.0 & 1.0 \\
\hline FRet & 127 & -0.005 & 0.034 & -0.022 & -0.001 & 0.013 \\
\hline LRet & 127 & -0.001 & 0.026 & -0.015 & -0.005 & 0.013 \\
\hline PreRet & 127 & -0.002 & 0.022 & -0.013 & -0.001 & 0.009 \\
\hline AnnRet & 127 & -0.002 & 0.016 & -0.007 & -0.001 & 0.005 \\
\hline
\end{tabular}

This table reports descriptive statistics for the sample of credit rating change announcements that neither succeed nor cite a news event that occurred over the four trading days prior to the rating change announcement. Variable definitions are available in Appendix Table 11

sample. For upgrades, the pre-announcement period's mean and median returns resemble those in the full sample for all three agencies. As with the announcement period returns, the mean and median returns resemble those in the full sample for both downgrades and upgrades and for all three agencies. These results suggest that, while other news can explain leading period returns, they cannot explain the preannouncement and announcement period returns. In summary, Fig. 1 and Table 4 show that other news (i) can account for return patterns over the leading period, (ii) can only partially account for the pre-announcement period returns, and (iii) exert a rather minor impact on the announcement period returns.

To further examine the patterns we observe in Table 4, we partition our sample of rating changes without other corporate news into changes in long-term issuer ratings (hereafter issuer ratings) and changes in instrument ratings. Instrument ratings apply to a specific instrument or set of similar instruments (e.g., senior unsecured debt securities) - changes in these ratings only affect these specific issues. Issuer ratings refer to the agency's opinion about the overall creditworthiness of the issuer, and the rating changes affect all of the outstanding rated instruments for that issuer. For S\&P, the database we use separates issuer and instrument ratings. For Moody's and Fitch, we 

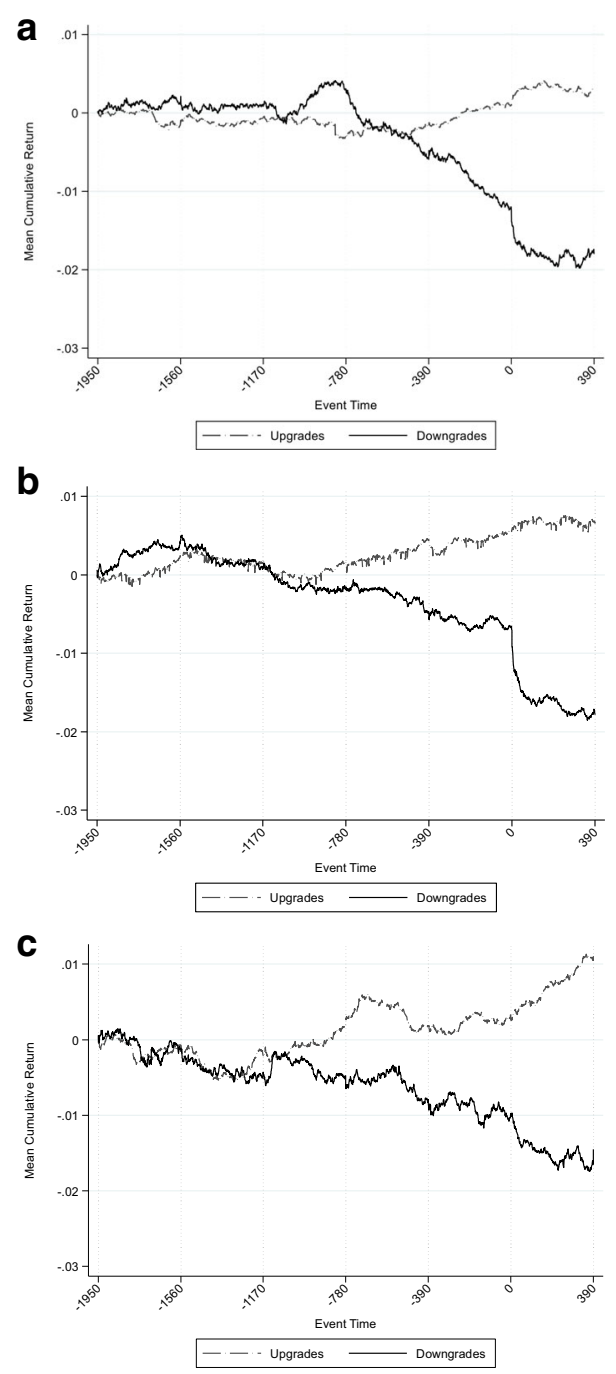

Fig. 1 Stock returns around rating change announcements without other news. Panel A: Standard \& Poor's. Panel B: Moody's. Panel C: Fitch. This figure shows mean cumulative stock returns for credit rating change announcements of S\&P (Panel A), Moody's (Panel B), and Fitch (Panel C) for the period starting 1950 trading minutes before through 390 trading minutes after a rating change announcement. The sample is restricted to credit rating change announcements that neither succeed nor cite a news event that occurred over the four trading days ending on the day of the rating change announcement. Minute 0 corresponds to the minute that a rating change is announced by the rating agency

manually classify each rating change by reviewing their press releases. Given that issuer ratings more accurately represent a company's overall health than instrument ratings, we expect them to affect stock prices more.

In Panel A of Table 5, we report results separately for issuer and instrument rating change announcements. We find that both the pre-announcement and announcement returns are generally significant for announcements of issuer rating changes but not for announcements of instrument changes. Among the former, announcements of 
Table 4 Stock returns around rating change announcements without other corporate news

\begin{tabular}{|c|c|c|c|c|c|c|c|c|c|c|}
\hline \multirow[b]{2}{*}{ Downgrades } & \multirow[b]{2}{*}{ S\&P } & \multirow[b]{2}{*}{ Mean } & \multirow{2}{*}{$\begin{array}{l}\mathrm{N} \\
412\end{array}$} & \multicolumn{2}{|c|}{$\begin{array}{l}\text { Fret } \\
{[-1950,120]}\end{array}$} & \multirow{2}{*}{$\begin{array}{l}\text { LRet } \\
{[-1950,-781]} \\
0.001\end{array}$} & \multicolumn{2}{|c|}{$\begin{array}{l}\text { PreRet } \\
{[-780,-2]}\end{array}$} & \multicolumn{2}{|c|}{$\begin{array}{l}\text { AnnRet } \\
{[-1,120]}\end{array}$} \\
\hline & & & & -0.016 & $* * *$ & & -0.012 & $* * *$ & -0.005 & $* * *$ \\
\hline & & Median & 412 & -0.008 & $* * *$ & 0.001 & -0.004 & $* * *$ & -0.002 & $* * *$ \\
\hline & Moody's & Mean & 198 & -0.016 & $* * *$ & -0.002 & -0.005 & $* *$ & -0.009 & $* * *$ \\
\hline & & Median & 198 & -0.011 & $* * *$ & 0.000 & -0.004 & $* *$ & -0.005 & $* * *$ \\
\hline & Fitch & Mean & 64 & -0.015 & $* * *$ & -0.005 & -0.005 & $*$ & -0.005 & $* *$ \\
\hline & & Median & 64 & -0.011 & $* * *$ & $-0.006^{*}$ & -0.003 & $*$ & -0.003 & $* *$ \\
\hline \multirow[t]{6}{*}{ Upgrades } & $\mathrm{S} \& \mathrm{P}$ & Mean & 365 & 0.004 & & -0.001 & 0.004 & $* *$ & 0.002 & $* *$ \\
\hline & & Median & 365 & 0.004 & $*$ & 0.000 & 0.002 & $* *$ & 0.001 & $* *$ \\
\hline & Moody's & Mean & 204 & 0.007 & $* *$ & 0.002 & 0.004 & $* *$ & 0.001 & \\
\hline & & Median & 204 & 0.007 & $* *$ & 0.003 & 0.005 & $* * *$ & 0.001 & $* *$ \\
\hline & Fitch & Mean & 63 & 0.005 & & 0.002 & 0.002 & & 0.001 & \\
\hline & & Median & 63 & 0.003 & $*$ & 0.000 & 0.003 & & 0.000 & \\
\hline
\end{tabular}

This table presents mean and median returns around credit rating change announcements that neither succeed nor cite a news event that occurred over the four trading days prior to the rating change announcement. Minute zero corresponds to the minute the rating agency announces a credit rating change. Variable definitions are available in Appendix Table 11. ${ }^{* * *},{ }^{* *}$, and ${ }^{*}$ denote significance at the $1 \%, 5 \%$, and $10 \%$ levels for twotailed t-tests (Wilcoxon tests for medians), respectively

downgrades are linked to statistically and economically significant negative returns across the three agencies. In contrast, upgrade announcements yield small and insignificant stock returns, with the exception of S\&P's. Pre-announcement returns for downgrades are also statistically significant and economically meaningful for all three agencies, and the mean values range between $-0.8 \%$ and $-1.3 \%$. For upgrades, we find significant pre-announcement returns for S\&P's and Moody's. With regard to announcements of instrument rating changes, returns are statistically insignificant and economically small across the board, with the exception of pre-announcement returns for S\&P's downgrades. Thus our results demonstrate that the pre-announcement stock price movements are driven by announcements of issuer rating changes and that there is little price reaction to announcements of instrument rating changes.

To further examine whether other pricing components that can influence credit risk also affect the information content of a rating change, we expand our analysis in several ways. First, we partition issuer and instrument rating changes by rating class: investment grade (i.e., BBB-/Baa3 or above) and speculative grade (i.e., below BBB-/Baa3). Given that default risk is greater in the speculative grade category, following Goh and Ederington (1999), we expect stock prices to exhibit greater sensitivity to rating changes for these observations. Panel B of Table 5 provides the results of this analysis. For brevity's sake, results are not broken out by rating agency. ${ }^{18}$ Panel B shows that at the issuer level, consistent with our conjecture, the pre-announcement and announcement period stock returns around rating changes are generally stronger for speculative

\footnotetext{
${ }^{18}$ While magnitudes and statistical significance levels vary, all of our inferences remain the same when we break the results out by rating agency.
} 


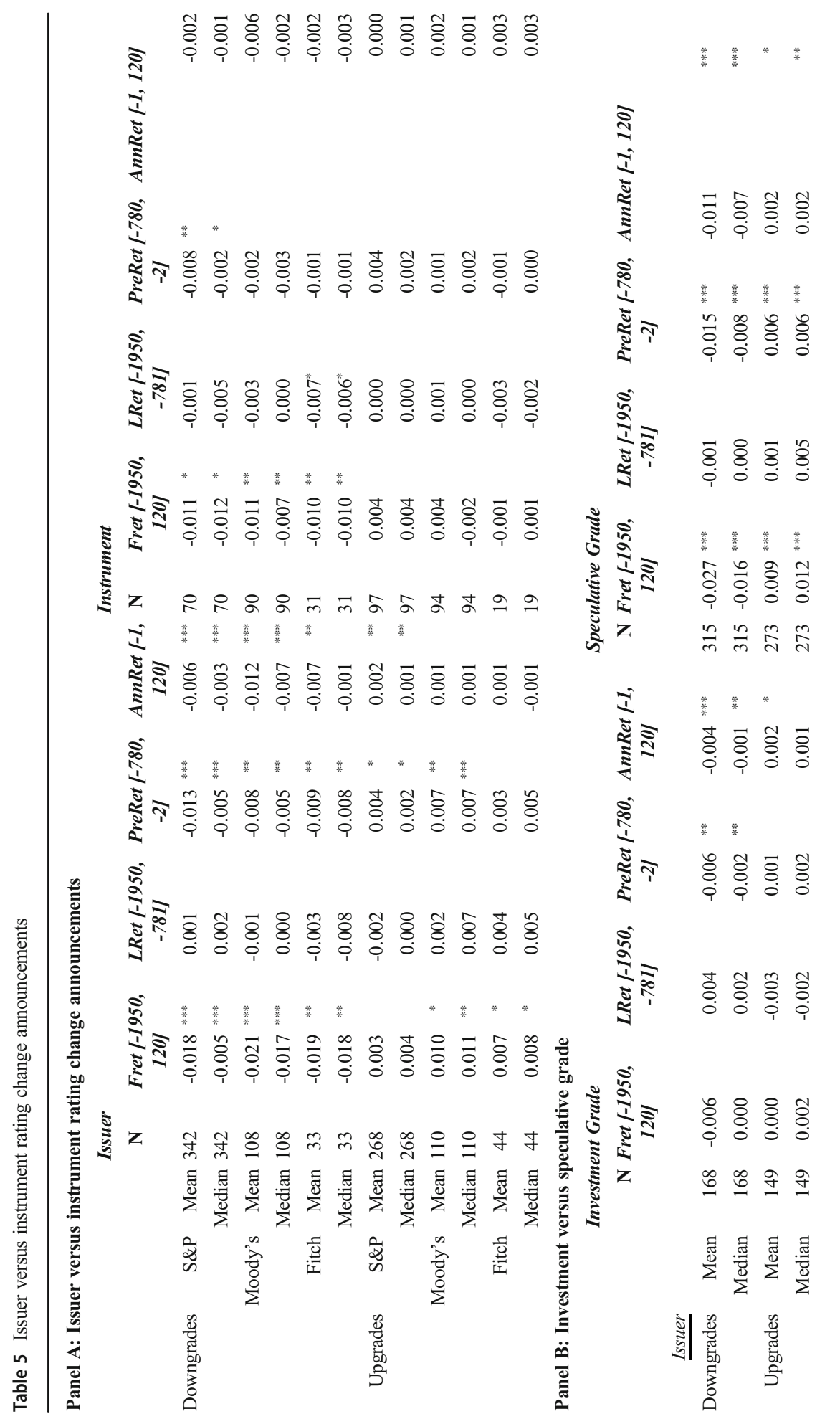




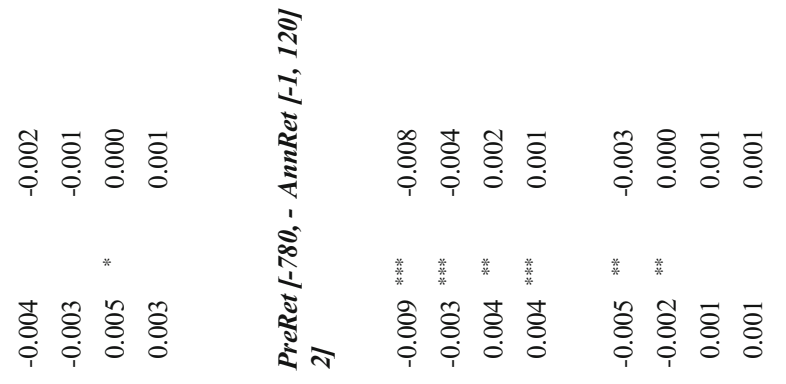

$\stackrel{0}{: \Xi \frac{0}{3}}$

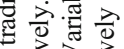

言

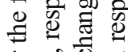

वे

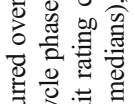

卷: 总

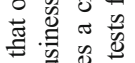

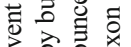

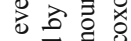

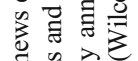

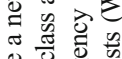

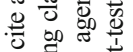

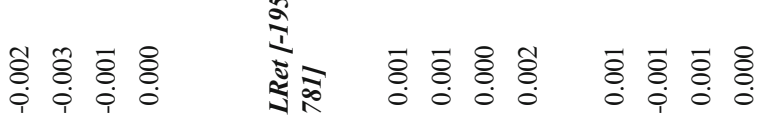

言密要

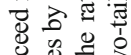

क

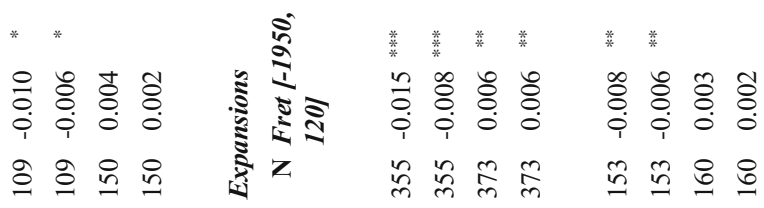

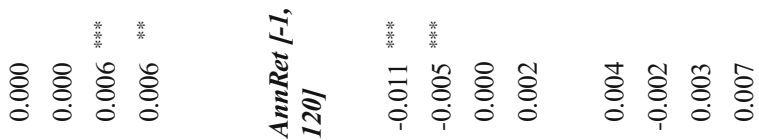

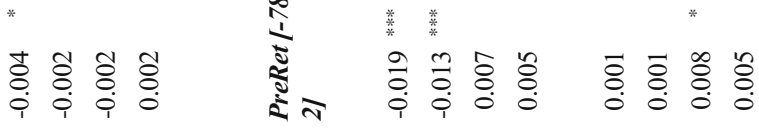

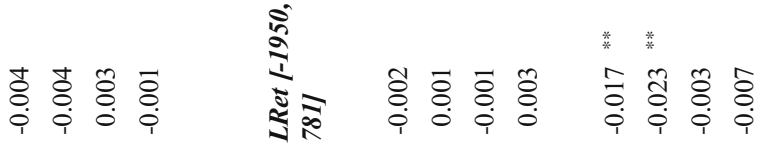

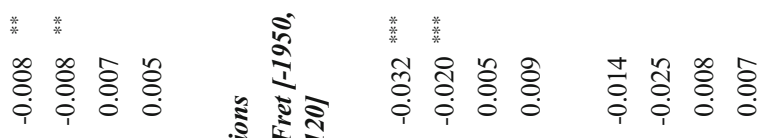

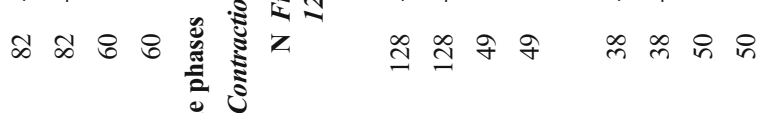

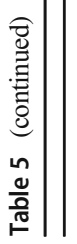

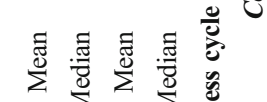

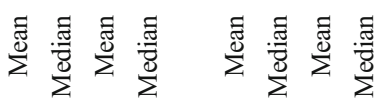

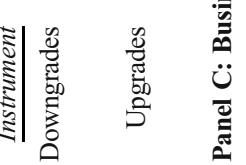

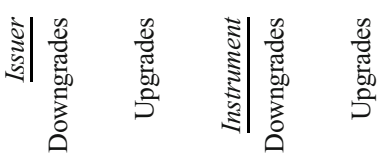

可 氖要 茞运 00

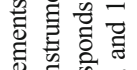
ठ⿹ की

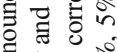

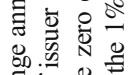
氜范完 on: 응

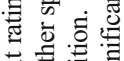

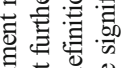
豆造 当造总 चै 可 尝

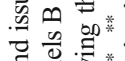
氙运 을

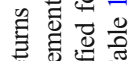
记

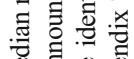

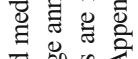

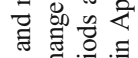
范 焉串 氙记

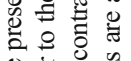

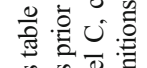

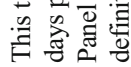


grade issuers. Downgrades are associated with an announcement return of $-1.1 \%$ for speculative grade and $-0.4 \%$ for investment grade. Similarly, the mean preannouncement return for downgrades is $-1.5 \%$ and $-0.6 \%$ for speculative and investment grade issuers, respectively. Nevertheless, at least for downgrades, we find that the pre-announcement and announcement returns are statistically significant for both subsamples. In contrast, for instrument rating changes, with few exceptions, these returns are insignificant. ${ }^{19}$

Second, we partition the sample based on whether credit rating changes are issued during a period of economic contraction or expansion. Our sample includes two contractions, according to NBER's definition of business cycles: March-November 2001 and December 2007-June 2009. Studies find that rating agencies positively adjust their models during expansions and that rating quality is not consistent over time (e.g., Griffin and Tang 2011; Auh 2015). Thus a plausible supposition is that stock price reaction to credit rating changes varies across business cycles. Panel $\mathrm{C}$ of Table 5 provides the results when we split our sample into contractions and expansions. Again, for brevity's sake, results are not broken out by rating agency, but our inferences remain similar across all three agencies. Panel $\mathrm{C}$ shows that the mean stock price reaction around downgrades of issuer ratings during contractions is $-3.2 \%$, compared to $-1.5 \%$ during expansions. The announcement and pre-announcement returns are statistically and economically significant during both periods. For upgrades, the magnitudes of pre-announcement and announcement returns are comparable between contraction and expansion periods but only those during the expansion periods are statistically significant. For changes in instrument ratings, we once again observe mostly economically small and statistically insignificant results for both downgrades and upgrades, regardless of business cycle stage.

In additional untabulated analyses, we examine whether stock prices respond differently to rating changes that are accompanied by a change in outlook or watch status in the same direction. These changes in status indicate the possible direction of a future rating change and therefore may increase the announcement's level of informativeness. In these tests, we find that our results for issuer and instrument ratings remain similar, regardless of whether the rating change is accompanied by a change in outlook or watch status.

Focusing on instrument ratings, we also examine our results based on the instrument's maturity. Refinancing represents a source of greater concern for instruments with short maturities than those with longer ones. Rating changes of short-maturity instruments may exert a stronger effect than long-maturity instruments on stock prices. However, we find that maturity does not influence our results. In summary, we show that Table 4's results are driven by announcements of changes in issuer ratings and that stock prices on average do not respond to announcements of changes in instrument ratings. Additional splits of the samples based on rating classes and business cycle phases do not alter these conclusions, but they do suggest that price response to rating

\footnotetext{
${ }^{19}$ In untabulated analyses, we also compare our results based on whether there is a transition from or to speculative grade. We find that, for issuer ratings, downgrades from investment to speculative grade are associated with a significant $-1.3 \%$ mean pre-announcement return and a statistically insignificant $-0.6 \%$ mean announcement period return. For instrument ratings, we continue to find insignificant results in both transitions. However, we caution that sample sizes in these analyses are small.
} 
changes exhibits some variation based on these factors. Given these results, we focus on issuer rating changes in the remainder of our analysis.

\subsubsection{The role of investor anticipation of rating changes}

Investors may anticipate a rating change based on publicly available information. This could explain the price patterns we observe ahead of rating changes. Studies find that credit rating agencies react to new information slowly (e.g., Pinches and Singleton 1978; Beaver et al. 2006; Cheng and Neamtiu 2009). Rating agencies concede that a trade-off between timeliness and stability informs rating actions (e.g., Cantor and Mann 2006). However, despite the lags, rating change announcements exert a significant impact on stock prices, possibly because they reveal new information (e.g., Agarwal et al. 2016) and because they figure in issuers' debt contracts, help determine exposures of asset management firms, and have regulatory implications. ${ }^{20}$

To examine whether investor anticipation of rating changes leads to the stock price patterns we observe during the pre-announcement period, we consider three variables as proxies for investor anticipation: prior period stock returns, prior period CDS spread changes, and prior period bond returns. Given the absence of other corporate news, there is little reason to expect that investors' anticipation of a rating change will surface about two trading days before the announcement, but that is precisely what we observe. Therefore we predict that the stock returns prior to the pre-announcement period would be significantly correlated with the pre-announcement period returns in the presence of investor anticipation of rating changes. We use prior period changes in CDS spreads and bond returns to proxy for investor anticipation. Research suggests that CDS spreads react strongly to credit events and that information flows from the debt market and specifically the CDS market influence stock prices. For example, Norden (2017) examines 31 U.S. and 64 international firms and finds that CDS spreads react strongly to negative news prior to downgrades. Chava et al. (2012) conclude that stock prices react less to rating changes when issuers have CDS contracts on their debt, suggesting that CDS trading facilitates the impounding of information about creditworthiness into stock prices. Acharya and Johnson (2007) document that information flows from the CDS market to the stock market. ${ }^{21}$ If the equity market is less efficient than the bond or CDS markets in incorporating information about an issuer's creditworthiness, then CDS spreads or bond prices should better reflect investor anticipation of rating changes.

To investigate whether investor anticipation is driving the pre-announcement period returns, we test whether their economic or statistical significance decreases after controlling for prior period stock and bond returns, changes in CDS spreads, and availability of CDS and bond trading. We estimate the following linear model.

\footnotetext{
${ }^{20}$ For example, Primary Market Corporate Credit Facility established by the Federal Reserve in response to the COVID-19 crisis is available only to investment grade issuers. See https://www.newyorkfed.org/markets/ primary-and-secondary-market-faq/corporate-credit-facility-faq

${ }^{21}$ Findings in some other studies contest these results. For example, Forte and Pena (2009) and Norden and Weber (2009) find that stock prices lead CDS spreads more often than the other way around.
} 


$$
\begin{aligned}
\text { PreRet }_{f}= & \alpha+\beta_{1} \text { LRet }_{f}+\beta_{2} \text { LWRet }_{f}+\beta_{3} \text { CDS }_{f}+\beta_{4} C D S_{f} \times \Delta \text { CDS_Spread }_{f} \\
& +\beta_{5} \text { Bond }_{f}+\beta_{6} \text { Bond }_{f}{\text { xBond } \text { Ret }_{f}+\beta_{7} \text { MarketRet }_{f}+\varepsilon}
\end{aligned}
$$

where the dependent variable, PreRet, is the issuer's cumulative stock return over the pre-announcement period. LRet is the issuer's cumulative stock return over the leading period. LWRet is the issuer's cumulative stock return between 20 and five trading days before the rating change announcement. $C D S$ is an indicator variable equal to one if the issuer has a CDS contract that is actively traded between 20 and two trading days before the rating change announcement and zero otherwise. $\triangle C D S$ Spread is the change in the issuer's CDS spread between 20 and two trading days before the rating change announcement. Bond is an indicator variable equal to one if at least one of the issuer's bonds is actively traded between 20 and two trading days before the rating change announcement and zero otherwise. BondRet is the value-weighted mean cumulative return of the issuer's bonds between 20 and two trading days before the rating change announcement. MarketRet is the value-weighted cumulative stock return of all firms listed in CRSP between two trading days before the rating change announcement and the day of the announcement. We obtain data on CDS availability and spreads from Bloomberg. We gather data on bond prices from the Trace database and calculate bond returns following Even-Tov (2017). To account for the fact that investor anticipation can occur over a short or long horizon, we separately include leading period returns (LRet) and long-term stock returns (LWRet). Given the relative illiquidity of the bond and CDS markets, we measure these variables only over the long term. Since the bond market is rather illiquid and BondRet is equal to zero in many cases, we include the Bond dummy to better estimate the effect of BondRet. We include MarketRet to account for any common shocks that affect the market during the pre-announcement period.

The variable of interest in Eq. (1) is the intercept $(\alpha)$, which captures the preannouncement returns remaining after controlling for investor anticipation. To the extent investor anticipation drives the pre-announcement period returns, $\alpha$ would become economically smaller and statistically weaker. To account for the possibility that industry-level shocks affect the pre-announcement period returns, we test an alternative specification, where we measure the dependent variable using three-digit SIC industry-adjusted returns (Abn_PreRet). ${ }^{22}$

We report results from the estimation of Eq. (1) and its aforementioned variant in Table 6 . For downgrades, $\alpha$ remains statistically and economically significant in both specifications (raw and abnormal returns) and for all three rating agencies. It ranges between $-0.8 \%$ and $-1.3 \%$, suggesting that measures of investor anticipation can only explain a relatively small fraction of PreRet for downgrades. Depending on the specification, prior period stock returns and changes in CDS spreads also impact returns. Bond returns are significant in both models for Moody's and are insignificant in both models for S\&P and Fitch. Market returns are significant in both models for S\&P and Fitch and are insignificant for Moody's. For upgrades, we find that $\alpha$ is only

\footnotetext{
$\overline{22}$ To calculate industry returns, we exclude the sample firm and impose the same TAQ data requirements as in our main sample. We lose 164 observations across the three agencies, due to the lack of required data.
} 


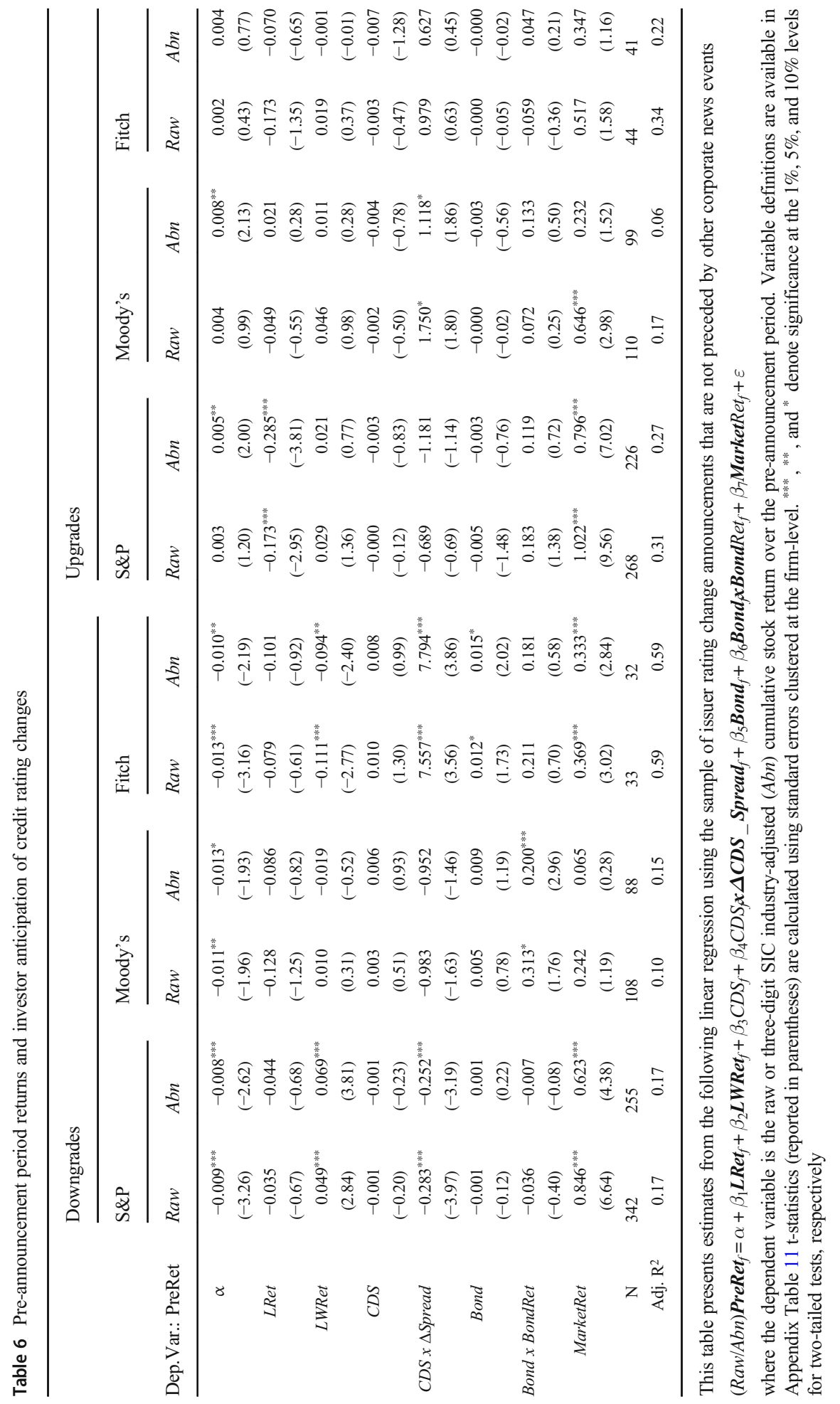


statistically significant when the dependent variable is abnormal returns and only for S\&P and Moody's after controlling for measures of investor anticipation. In summary, results from the analyses reported in Table 6 indicate that, although corporate news, investor anticipation of rating changes, and market or industry shocks to stock prices can account for the pre-announcement period returns for upgrades, they have limited explanatory power for returns for downgrades during the same period.

\subsubsection{The role of privately informed parties}

Informed trading ahead of rating changes represents a third possible explanation for pre-announcement period price patterns. Two parties are privately informed about a future rating change: the issuer's insiders and the rating agency's analysts. ${ }^{23}$ In this section, we consider each party's incentives to exploit this information to assess whether informed trading contributes to pre-announcement period return trends.

Two factors support the conjecture that informed trading influences preannouncement period stock returns. First, the pre-announcement period coincides with the window during which agencies finalize rating decisions and inform issuers directly. In a typical scenario, rating committees notify the issuer privately about their decision shortly after determination of a rating change but before its public announcement. The notification is intended to verify accuracy and to eliminate risk of unintentional disclosure of confidential information in the ratings report. The issuer can confirm, object, suggest modifications, or decline to respond to this notification. Unless the issuer offers new material information that can affect the decision, the rating change is publicized via the agency's website, often within $24 \mathrm{~h}$ and generally no more than $48 \mathrm{~h}$ following the agency's decision. ${ }^{24}$ As this timeline indicates, the period between the rating committee's decision and its public announcement corresponds roughly to the pre-announcement period. This raises the possibility that informed trading contributes to the significant pre-announcement period returns that we observe. Price movements are particularly pronounced around downgrades, which leads to the second factor supporting our contention. Since downgrades elicit a stronger price response than upgrades, there is greater incentive to trade on the private information before their announcement. Thus the stronger pre-announcement price movements we observe before downgrades suggest informed trading.

\footnotetext{
${ }^{23}$ All three rating agencies in our sample operate on issuer-paid basis when assigning credit ratings in the United States. This implies that investors should not be aware of the ongoing ratings process unless the analyst or the issuer shares this information.

${ }^{24}$ For example, S\&P's Corporate Ratings Criteria (2002) states: “Once the rating is determined, the company is notified of the rating and the major considerations supporting it. It is Standard \& Poor's policy to allow the issuer to respond to the rating decision prior to its publication by presenting new or additional data. Standard \& Poor's entertains appeals in the interest of having available the most information possible and, thereby, the most accurate ratings. In the case of a decision to change an extant rating, any appeal must be conducted as expeditiously as possible, i.e., within a day or two. The committee reconvenes to consider the new information. After notifying the company, the rating is disseminated in the media — or released to the company for dissemination in the case of private placements or corporate credit ratings." The timeline is similar for Moody's and Fitch. Details of Moody's criteria are available at https://www.moodys.com/Pages/ amr002001.aspx, and details of Fitch's criteria are available at https:/www.fitchratings.com/research/ structured-finance/the-ratings-process-22-05-2019.
} 
Private information about an upcoming rating change can be incorporated into prices by issuers' insiders or credit analysts. Anecdotal evidence suggests that both parties may profit from their knowledge of confidential information. For example, in one highprofile case, Linda Lay, the wife of Enron's former chairman, Kenneth Lay, sold about half a million shares shortly before S\&P lowered Enron's credit rating to junk status on November 28, 2001 (Eichenwald 2004). In 2009, in one of the biggest insider trading cases in U.S. history, a Moody's credit analyst was charged with providing a hedge fund with confidential information in return for cash (Lattman 2011). Similarly, in 2004, an S\&P credit analyst was charged for trading on confidential information regarding S\&P's clients and sharing this information with a friend (Goldstein 2004). Prior research documents insider trading ahead of bankruptcies and covenant violations (Seyhun and Bradley 1997; Beneish et al. 2011; Griffin et al. 2014). Similar incentives for insider trading may exist around credit rating changes, which less severely harm firm value but are more common than bankruptcies and covenant violations. Credit analysts can benefit from their knowledge of upcoming rating changes by either directly trading or tipping off other parties in return for future employment opportunities. Studies reveal that credit analysts inflate the ratings of securities issued or underwritten by their future employers prior to switching jobs (Cornaggia et al. 2016; Jiang et al. 2018; Kempf 2020). Similar labor market benefits may incentivize analysts to selectively share information with institutional investors.

We begin our analysis of informed trading in advance of credit rating changes by focusing on trading by issuers' insiders ahead of these announcements. We follow the methodology of Dechow et al. (2016), who compare daily average insider trading over the pre-announcement period with that over a control period. We obtain data on insider trades from the Thomson Reuters database and that pertaining to shares outstanding from CRSP. Since insider trading data is available on a daily basis, we define preannouncement period as the three trading days ending on the day of the rating change. Given the infrequency of insider trades, we measure the "normal" level of insider trades as the average insider trade over the 50 days ending 10 days before the rating change announcement date. ${ }^{25}$ For each day, we calculate insider buys (sells) as the total insider purchases (sales) divided by the number of shares outstanding and compare the average value over the control and pre-announcement periods. Due to insider trading data availability, our sample sizes for this analysis are 315, 108, and 33 downgrades and 234, 110, and 44 upgrades for S\&P, Moody’s, and Fitch, respectively.

Table 7 displays the comparison of insider trades over the pre-announcement and control periods. We report values for insider purchases (Insider_Buys) and sales (Insider_Sells) in basis points. Our results indicate a significant reduction at the 5\% level in insider buys during the pre-announcement periods, compared to during the control periods, for Moody's and Fitch downgrades but an insignificant change for S\&P. For insider sales prior to downgrades, there are significant reductions across all three rating agencies. With respect to upgrades, we find only a marginally significant reduction in insider sells for S\&P upgrades and a significant reduction in insider buys prior to Fitch upgrades. Overall, the findings in Table 7 show evidence that insiders alter their trading ahead of rating changes, suggesting they exploit their private

\footnotetext{
${ }^{25}$ Our inferences are generally robust to various 20 - and 50-day windows before or after the rating change announcement.
} 
Table 7 Issuer insiders' trades ahead of credit rating changes

\begin{tabular}{|c|c|c|c|c|c|c|c|}
\hline & & & $\mathrm{N}$ & Control & Pre-Ann. & Diff. & \\
\hline \multirow[t]{6}{*}{ Downgrades } & $\mathrm{S} \& \mathrm{P}$ & Insider_Buys & 315 & 0.07 & 0.28 & 0.21 & \\
\hline & & Insider_Sells & 315 & 0.056 & 0.02 & -0.036 & $*$ \\
\hline & Moody's & Insider_Buys & 108 & 0.07 & 0.01 & -0.07 & $* *$ \\
\hline & & Insider_Sells & 108 & 0.08 & 0.00 & -0.08 & $* * *$ \\
\hline & Fitch & Insider_Buys & 33 & 0.003 & 0.002 & -0.001 & $* *$ \\
\hline & & Insider_Sells & 33 & 0.036 & 0.002 & -0.034 & $* *$ \\
\hline \multirow[t]{6}{*}{ Upgrades } & $\mathrm{S} \& \mathrm{P}$ & Insider_Buys & 234 & 0.01 & 0.01 & 0.00 & \\
\hline & & Insider_Sells & 234 & 2.44 & 0.04 & -2.40 & $*$ \\
\hline & Moody's & Insider_Buys & 110 & 1.07 & 0.01 & -1.06 & \\
\hline & & Insider_Sells & 110 & 0.09 & 7.20 & -7.11 & \\
\hline & Fitch & Insider_Buys & 44 & 0.02 & 0.00 & -0.02 & $* *$ \\
\hline & & Insider_Sells & 44 & 0.11 & 0.09 & -0.02 & \\
\hline
\end{tabular}

This table presents changes in insider trading ahead of issuer rating changes. Pre-announcement period is defined as the three trading days ending on the day of the rating change, and control period is defined as the 50-trading day window ending 10 trading days before the rating change announcement. Average insider purchases (sales) are reported in basis points and are measured as the average daily number of shares insiders purchased (sold) divided by shares outstanding over each period. The last column reports the difference between pre-announcement period and control period. ${ }^{* * *},{ }^{* *}$, and ${ }^{*}$ denote significance at the $1 \%, 5 \%$, and $10 \%$ levels for two-tailed tests, respectively

information. However, since they reduce their trading, they likely aim to avoid regulatory or investor scrutiny. Therefore, while the results indicate that insiders are aware of the rating change in advance of its announcement, they cannot explain the preannouncement returns that we observe.

Next, we examine the role credit analysts play in sharing confidential information prior to credit rating changes. Unless an analyst is prosecuted for insider trading, there is no clear way of knowing whether that person has directly benefitted from foreknowledge of rating changes. As an anecdotal evidence, our sample includes at least one analyst who was imprisoned for trading on private information regarding two upcoming rating changes. To generate statistical evidence, we focus on another data stream, the analyst's subsequent career path. Specifically, we consider whether credit analysts are motivated to share information with asset or portfolio management firms that they will subsequently work for. Research demonstrates that credit analysts inflate securities ratings issued by or underwritten by their future employers before switching jobs (Cornaggia et al. 2016; Jiang et al. 2018; Kempf 2020). We consider similar career incentives as a motivation for analysts' information sharing in our setting.

We examine the magnitude of pre-announcement period returns using data that reflect their career outcomes. We use this outcome as an indicator of whether the analyst named on a credit rating report was pursuing a position at an asset or portfolio management firm. We separate our sample of rating announcements into two groups, split according to whether the analyst's first position after leaving the rating agency was at an asset or portfolio management firm. ${ }^{26}$ To begin this process, for each observation

\footnotetext{
${ }^{26} \mathrm{We}$ include banking and insurance firms in this classification.
} 
in our sample, we search for the rating report or press release and extract the name of the analyst(s) from these documents. Most reports in our sample name one or two analysts. We then extract analysts' career outcomes from professional networking sites, such as LinkedIn.com. Out of the 905 observations in our sample, we identify the analyst name and career outcome for 788, about 87\%. In 215 observations, the analyst's first job after leaving the rating agency is with an asset or portfolio management firm $($ Career_Path $=1)$, and, in 573 observations, the analyst either stays at the rating agency, retires, or switches to a position in a non-asset or portfolio management firm, typically at another rating agency or a nonprofit organization $($ Career_Path $=0){ }^{27}$

Table 8 presents the results from this analysis. Panel A displays returns around downgrade and upgrade announcements, and Panel B presents results from the following ordinary least squares model.

$$
\begin{aligned}
\text { PreRet }_{f}= & \alpha+\delta_{1} \text { Career_Path }+\delta_{2} \text { LRet }_{f}+\delta_{3} \text { LWRet }_{f}+\delta_{4} \text { CDS }_{f} \\
& +\delta_{5} \text { CDS }_{f} \boldsymbol{x} \boldsymbol{\Delta} \boldsymbol{C D S}_{\text {Spread }_{f}}+\delta_{6} \text { Bond }_{f}+\delta_{7} \text { Bond }_{f} \mathrm{xBond}_{\text {Ret }} \\
& +\delta_{8} \text { MarketRet }_{f}+\varepsilon
\end{aligned}
$$

where Career_Path is a dummy variable equal to one if the subsequent position of at least one of the credit analysts named on the rating report is with an asset or portfolio management firm and zero otherwise. All other variables are as defined in Eq. (1). In untabulated analyses, we define Career_Path based on whether the job transition occurs within the five-year window after the rating announcement and find that our inferences for S\&P and Moody's remain unchanged.

Panel A of Table 8 displays results for both career path subsamples. Similar to the findings in Table 4, the leading period stock returns are insignificant in both subsamples for upgrades and downgrades across all three rating agencies. The primary difference in returns between the two subsamples appears in the pre-announcement and announcement periods. For S\&P and Moody's, we find statistically and economically significant returns during the pre-announcement period ahead of downgrades in the subsample where we expect the career path to have an effect (Career_Path $=1$ ). Specifically, the mean stock return over the pre-announcement period is $-2.2 \%$ $(p<0.01)$ for S\&P downgrades and $-1.9 \%(\mathrm{p}<0.01)$ for Moody's. The median returns are also statistically significant. With respect to downgrades by Fitch, we find statistically insignificant stock returns in the pre-announcement period $(-1.6 \%)$, possibly due to this agency's smaller representation in our sample.

For the subsample where we do not expect career path to have an effect $($ Career_Path $=0)$, we find smaller and largely insignificant returns over the preannouncement period and significant returns over the announcement period across all three agencies. The mean returns over the pre-announcement period are $-0.8 \%,-0.3 \%$ and $-0.7 \%$ for downgrades by S\&P, Moody's and Fitch, respectively. With respect to the announcement returns, we find insignificant (significant) announcement returns for

\footnotetext{
$\overline{27}$ Our inferences are unaffected if we remove an S\&P analyst who was fired for insider trading and is classified as Career_Path $=1$.
} 


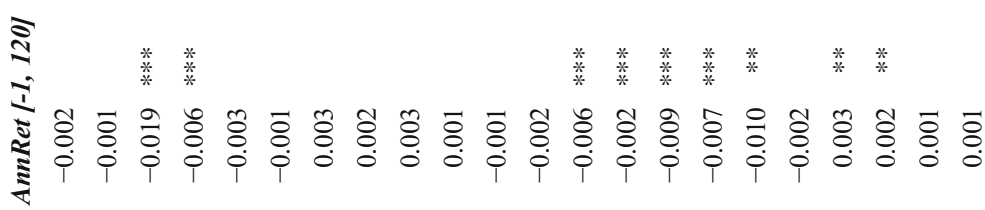

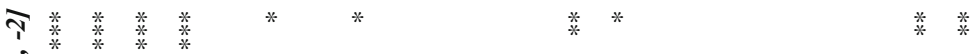

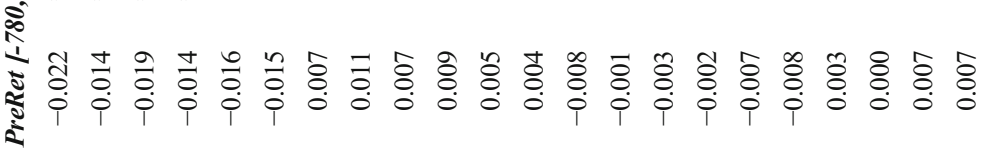

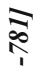

เู

范

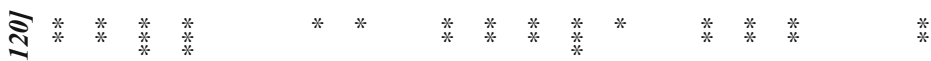

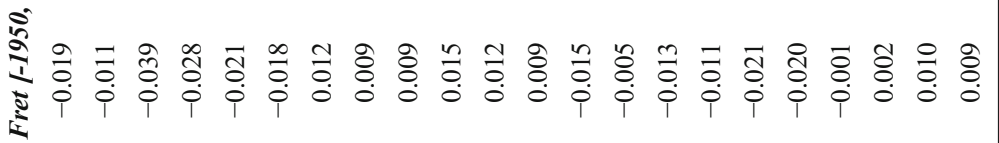

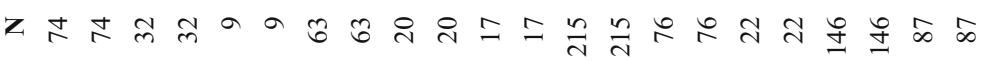

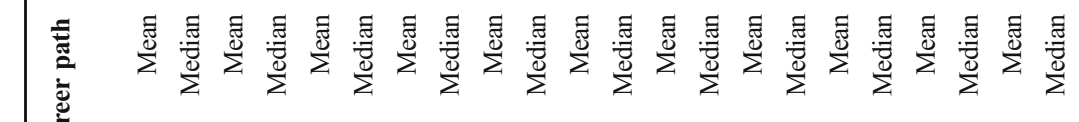

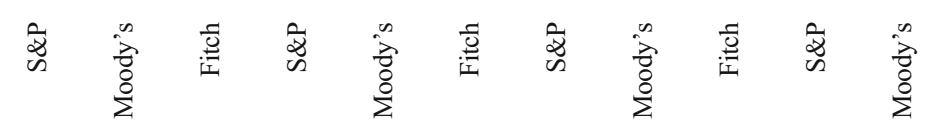

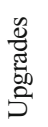

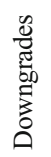




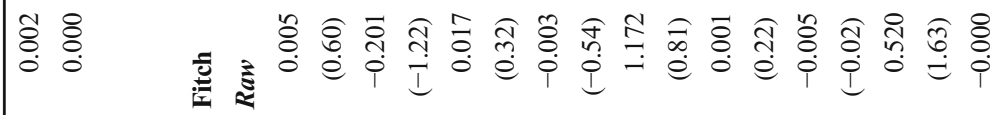

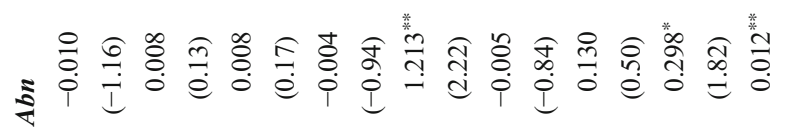

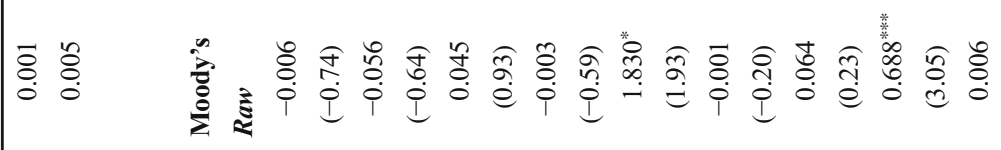

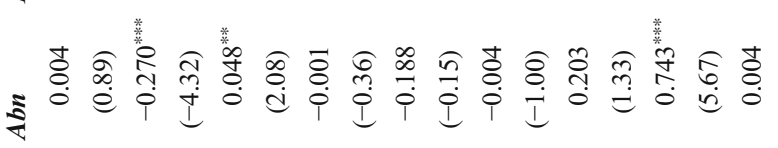

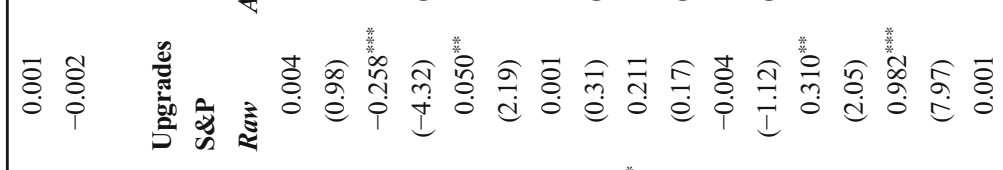

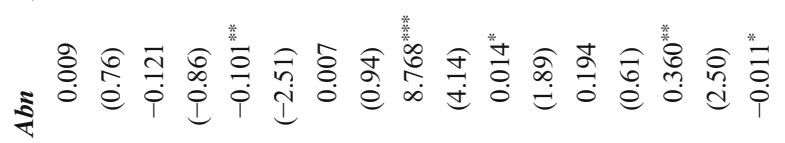

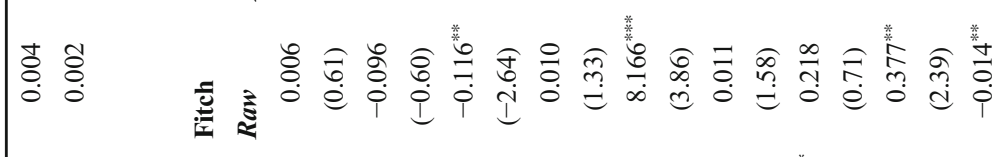
त̄

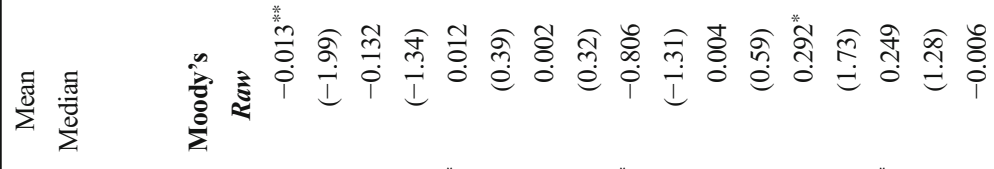
崫

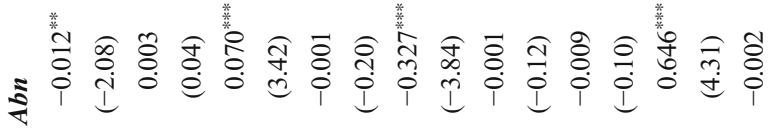

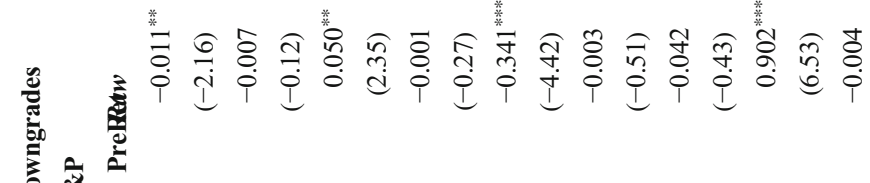
$\theta$ 宆

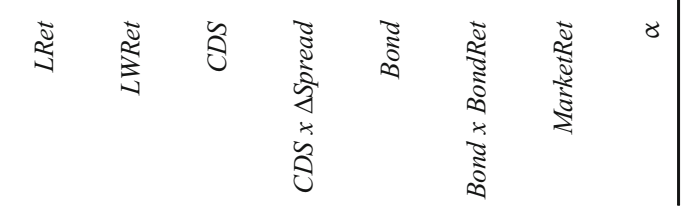




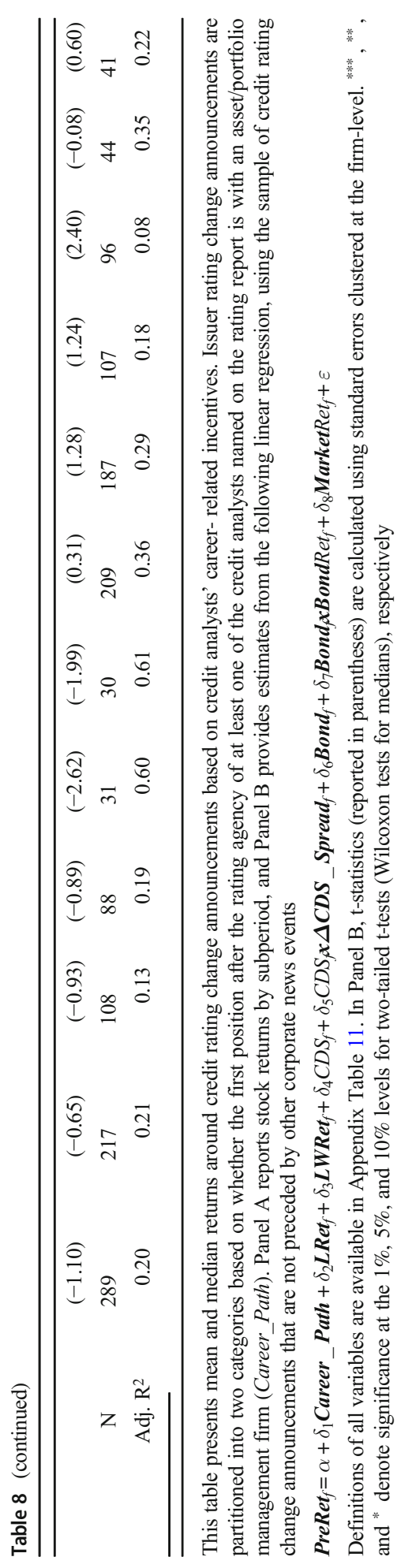


S\&P (Moody's), where there are career-related incentives at play, and significant announcement returns for both S\&P and Moody's, where there appear to be no career-related incentives. This discrepancy highlights how considerations of professional advancement linked to information leakage result in a smaller price reaction than do instances where such considerations and activity are absent.

For upgrades, returns are mostly statistically insignificant during the pre-announcement and announcement periods in both subsamples. The overall findings suggest that, when career incentives exist, there is a stronger stock price movement in the direction of an upcoming rating change during the pre-announcement period and, in the case of S\&P and Fitch, a weaker reaction during the announcement period. This result is consistent with evidence of credit analysts' private information leakage.

Table 8, Panel B, presents results from our estimation of the model defined by Eq. (2). The estimates in the first four columns suggest that Career_Path remains statistically significant after controlling for investor anticipation proxies for downgrade announcements by S\&P and Moody's. The size of the coefficient varies between $-1.1 \%$ and $-1.6 \%$. For upgrades, we find that Career_Path is statistically insignificant for all three rating agencies. These findings support the conclusions we draw from Panel A and are generally consistent with stronger pre-announcement period returns for announcements correlating with greater incentives for credit analysts to leak private information.

\subsection{Who benefits from trading ahead of rating change announcements?}

Our previous analyses indicate that the presence of other corporate news, investor anticipation, and leakage of private information can impact pre-announcement returns for credit rating changes. Our findings suggest that analysts might be sharing information about upcoming rating changes with certain institutional investors. In this section, we test this conjecture by examining trade imbalances and relative trading volumes of retail and institutional investors ahead of credit rating changes.

We identify retail and institutional investor buy and sell orders, following Boehmer et al. (2019) and Farrell et al. (2018). Boehmer et al. highlight that most retail trading is fulfilled from the broker's own inventory or sold by the broker to wholesalers and that retail trades typically receive small price improvements (ranging from 0.01 to 0.2 cents) over the National Best Bid or Offer price, whereas institutional trades do not. They classify a trade as a retail purchase (sale) if the trade has a TAQ code of D and the trade price is just below (above) a round penny, which they define as 4/10 of one cent. Farrell et al. build on this approach. They identify a trade as an institutional purchase (sale) if the trade is classified as a buy (sell) based on the Lee and Ready (1991) algorithm and is not classified as a retail order per Boehmer et al. We follow these two studies in identifying retail and institutional purchases and sales. Likewise, we begin our sample period in 2010, due to the absence of TAQ exchange codes before that point.

We measure retail and institutional investor trade imbalances and relative trading volumes over the pre-announcement period (i.e., $[-780,-2])$ and compare them with those during the leading period (i.e., $[-1950,-781])$. We measure relative trade volume (Ret_Vol/Inst_Vol) as the total dollar volume of retail buys and sells divided by the total dollar volume of institutional buys and sells for each period. We measure retail and 
institutional trade imbalances for the pre-announcement and leading periods using dollar values of trades as follows.

$$
\frac{\text { Retail }_{\text {Imb }}=\sum \text { Retail }_{\text {Buys }}-\sum \text { Retail }_{\text {Sells }}}{\sum \text { Retail }_{\text {Buys }}+\sum \text { Retail }_{\text {Sells }} .}
$$

$$
\frac{\text { Inst }_{\text {Imb }}=\sum \text { Inst }_{\text {Buys }-\sum \text { Inst }_{\text {Sells }}}}{\sum \text { Inst }_{\text {Buys }}+\sum \text { Inst }_{\text {Sells }} .}
$$

Table 9 documents our comparison of imbalances and volume over the leading and preannouncement periods. Due to the smaller dataset of Fitch's announcements, we lack enough observations to calculate these measures, and thus we only report results for S\&P and Moody's. For downgrades, institutional trade imbalance is positive (small and negative) during the leading period and large and negative during the preannouncement period for Moody's (S\&P), suggesting that institutional investors sell more than they buy over the pre-announcement period for downgrades. The differences

Table 9 Institutional and retail investor trading around rating change announcements

\begin{tabular}{crrrrrrr}
\hline & & $\mathrm{N}$ & $\begin{array}{l}\text { Leading Period } \\
{[-1950,-781]}\end{array}$ & $\begin{array}{l}\text { Pre-Ann.Period } \\
{[-780,-2]}\end{array}$ & Diff. & \\
& & & & & \\
\hline \multirow{2}{*}{ S\&P } & Inst_Imb & 62 & -0.012 & -0.061 & -0.050 & $* *$ \\
& Retail_Imb & 62 & -0.018 & 0.053 & 0.071 & $*$ \\
& Ret_Vol/Inst_Vol & 62 & 0.272 & 0.212 & -0.060 & $* * *$ \\
Downgrades & & & & & & \\
Moody's & Inst_Imb & 12 & 0.075 & -0.058 & -0.134 & $* * *$ \\
& Retail_Imb & 12 & -0.005 & -0.057 & -0.052 & \\
& Ret_Vol/Inst_Vol & 12 & 0.203 & 0.169 & -0.034 & $* * *$ \\
& Inst_Imb & 68 & 0.013 & -0.011 & -0.024 & \\
& Retail_Imb & 68 & -0.043 & -0.069 & -0.026 & \\
& Ret_Vol/Inst_Vol & 68 & 0.114 & 0.117 & 0.002 & \\
& & & & & & & \\
Upgrades & Inst_Imb & 27 & 0.027 & 0.052 & -0.025 & \\
Moody's & Retail_Imb & 27 & -0.005 & -0.002 & -0.003 & \\
& Ret_Vol/Inst_Vol & 27 & 0.073 & 0.078 & -0.005 & \\
\hline
\end{tabular}

This table presents the average institutional and retail investor trade imbalances and relative trading volumes over the leading and pre-announcement periods. For each period, institutional (retail) trade imbalances are calculated as the ratio of total institutional (retail) purchases minus total institutional (retail) sales to the sum of total institutional (retail) purchases and sales, all using dollar values. Relative trading volume (Ret_Vol/ Inst_Vol) is measured as the ratio of total dollar volume of retail buys and sells to the total dollar volume of institutional buys and sells for each period. The last column reports the differences and their statistical significance based on two-tailed t-tests. ${ }^{* * *},{ }^{* *}$, and ${ }^{*}$ denote significance at the $1 \%, 5 \%$, and $10 \%$ levels for two-tailed tests, respectively. The sample period is January 2010-June 2017 
of $-5.0 \%$ and $-13.4 \%$ for S\&P and Moody's, respectively, are statistically and economically significant at the $5 \%$ level. With respect to retail investors, we find that they buy more during the pre-announcement period for S\&P's downgrades. The difference between the two periods is $7.1 \%$ for $\mathrm{S} \& \mathrm{P}$ and statistically significant at the $10 \%$ level. For Moody's, we see an insignificant change in retail trading. Consistent with the individual trade imbalance measures, we find that the relative trade volume also displays a significant increase during the pre-announcement period in institutional trades, relative to retail trades, for both S\&P and Moody's. We generally observe no significant change in retail or institutional trade imbalances or relative volume between leading and pre-announcement periods around S\&P or Moody's upgrades.

Our findings in Table 9 corroborate Table 8's results, indicating that career-related incentives motivate credit analysts to share private information with institutional investors. Given that downgrades generate larger price reactions and hence opportunities for profit, we would expect greater incentives for leaking and trading on information prior to downgrades. The results reported in Table 8 support that contention. When viewed alongside the announcements' timeline, our findings suggest that leakage of private information in advance of credit rating change announcements could influence pre-announcement period returns.

\section{Conclusion}

We employ intraday analysis to isolate the information content of credit rating changes and provide novel evidence of information leakage ahead of these announcements. We show that credit rating analysts looking to change jobs likely disclose private information. Our study also indicates that institutional investors receive these leaks.

Our study offers one of the most comprehensive analyses of stock price reactions to credit rating changes to date and responds specifically to Griffin and Sanvicente's (1982) recommendation to employ intraday data to attain more accurate results. Given that most rating change announcements occur during trading hours, the use of intraday data is especially pertinent in our study. Our results advance this literature in several ways. Our analyses provide initial evidence on the variation in intraday timing of credit rating changes across rating agencies and between upgrades and downgrades. We also document that only announcements of issuer rating changes elicit a significant price reaction and that those for instrument rating changes are not broadly statistically significant. We conduct several other cross-sectional and longitudinal analyses. While we confirm studies that find that downgrades elicit a stronger price reaction than upgrades, through using intraday data, we show that this asymmetrical reaction is likely driven by the differential informativeness of upgrades and downgrades and not by other factors.

Our findings should interest regulators, who aim to ensure fair access to information for all investors; credit rating agencies, whose dissemination practices may allow improper sharing of information; and investors, whose trades may be front-run by parties with foreknowledge of rating changes. We hope that our study will inspire discussion and research on drivers and consequences of rating change announcements and their impact on the stock market. Another possible path for future research is to 
focus on the ratings process and implications of ratings for privately held firms and nonprofit organizations.

Acknowledgements We thank David Aboody, Brad Barber, Judson Caskey, Umit Gurun, Paul Griffin, Jack Hughes, Panos Patatoukas, Brett Trueman, an anonymous reviewer, and workshop participants at University of Rochester, UCLA, and UC Berkeley for useful discussions and helpful comments. We also thank Neri Bukspan, formerly at S\&P, and S\&P Global Ratings Research and Moody‘s Analytics help desks for clarifying institutional details of the ratings announcement process. We also thank Yihan Song and Lingyu $\mathrm{Gu}$ for their help with data collection.

\section{Appendix 1}

Table 10 Intraday distribution of credit rating changes

\begin{tabular}{|c|c|c|c|c|c|c|c|}
\hline & \multirow[b]{2}{*}{ Time of Day } & \multicolumn{2}{|c|}{ All Rating Changes } & \multicolumn{2}{|c|}{ Downgrades } & \multicolumn{2}{|c|}{ Upgrades } \\
\hline & & $\mathrm{N}$ & $\%$ & $\mathrm{~N}$ & $\%$ & $\mathrm{~N}$ & $\%$ \\
\hline \multirow[t]{4}{*}{$\mathrm{S} \& \mathrm{P}$} & Before Market Opens & 217 & $4.6 \%$ & 124 & $4.9 \%$ & 93 & $4.2 \%$ \\
\hline & Trading Hours & 3266 & $69.2 \%$ & 1669 & $66.3 \%$ & 1597 & $72.4 \%$ \\
\hline & After Market Closes & 1240 & $26.3 \%$ & 723 & $28.7 \%$ & 517 & $23.4 \%$ \\
\hline & Unknown & 0 & $0.0 \%$ & 0 & $0.0 \%$ & 0 & $0.0 \%$ \\
\hline \multirow[t]{4}{*}{ Moody's } & Before Market Opens & 84 & $2.5 \%$ & 47 & $2.5 \%$ & 37 & $2.4 \%$ \\
\hline & Trading Hours & 1957 & $57.8 \%$ & 1015 & $54.3 \%$ & 942 & $62.0 \%$ \\
\hline & After Market Closes & 1218 & $36.0 \%$ & 721 & $38.6 \%$ & 497 & $32.7 \%$ \\
\hline & Unknown & 129 & $3.8 \%$ & 85 & $4.6 \%$ & 44 & $2.9 \%$ \\
\hline \multirow[t]{4}{*}{ Fitch } & Before Market Opens & 82 & $8.3 \%$ & 39 & $6.9 \%$ & 43 & $7.1 \%$ \\
\hline & Trading Hours & 677 & $68.2 \%$ & 312 & $54.8 \%$ & 365 & $60.5 \%$ \\
\hline & After Market Closes & 234 & $23.6 \%$ & 131 & $23.0 \%$ & 103 & $17.1 \%$ \\
\hline & Unknown & 179 & $15.3 \%$ & 87 & $15.3 \%$ & 92 & $15.3 \%$ \\
\hline
\end{tabular}

This appendix reports the intraday distribution of rating change announcements in our sample

\section{Appendix 2 Examples of rating change announcements without additional news}

\section{MCGRAW HILL COMPANIES INC - S\&P: CROWN CASTLE INTERNATIONAL CORPORATE CREDIT RATING CUT TO ‘BB-’ FROM ‘BB'; OUTLOOK NEGATIVE}

Dec. 18, 2007- Standard \& Poor's Ratings Services said it lowered its ratings on Houston, Texas-based tower operator Crown Castle International Corp., including its corporate credit rating, which was cut to 'BB-' from 'BB.' The outlook is negative. The company had about \$6 billion of funded debt outstanding as of Sept. 30, 2007.

"The downgrade reflects our current expectation that Crown Castle's management is comfortable operating at a higher level of leverage than was anticipated in our previous 
rating even though we had expected the company to remain aggressive in repurchasing common stock," said Standard \& Poor's credit analyst Catherine Cosentino.

Management had indicated in their third-quarter earnings call on Oct. 31, 2007, that they expect leverage to be at the higher end of their $6 x-8 x$ target, which equates to about 9x under our adjusted leverage calculation. We had previously said that the ratings would be lowered if the company was not able to reduce debt to the low- $8 \mathrm{x}$ area in 2008.

The ratings on Crown Castle reflect the company's aggressive financial policy, which anticipates substantial repurchases of common stock and attendant high leverage, which was about 9x debt to annualized EBITDA, adjusted for operating leases, for the three months ended Sept. 30, 2007 (9.3x, including redeemable preferred stock).

Such high financial risk overshadows the company's strong business. A good portion of the assumed stock repurchases likely will be funded with additional debt, mostly in the form of securitized revenue notes, which can be issued subject to a $2 \mathrm{x}$ minimum securitization fixed-charge coverage ratio at the Crown Castle legacy securitization, and could exceed $\$ 1$ billion over the next several years.

Analyst Contact: Catherine Cosentino, New York (1) 212-438-7828.

\section{MOODY'S DOWNGRADES KELLWOOD'S SENIOR UNSECURED DEBT RATING TO BA3; AFFIRMS BA2 CORPORATE FAMILY RATING}

New York, May 10, 2006 - Moody's Investors Service affirmed the Ba2 corporate family rating for Kellwood Company and downgraded the senior unsecured debt rating to $\mathrm{Ba} 3$ from $\mathrm{Ba} 2$ following the completion of a secured asset based credit facility that replaced an unsecured revolving credit facility. The downgrade of the senior unsecured debt rating reflects the effective subordination of the remaining unsecured creditors to the new secured credit facility and the release of the subsidiary guarantees since they were linked to the terminated credit facility. The outlook remains negative.

Kellwood's ratings reflect the diversification by brand, product category and price point. The company is the largest marketer of dresses in the United States and is a major manufacturer of shirts through its Smart Shirts subsidiary. The ratings are also supported by the company's ample liquidity. On the downside, the ratings consider the challenges the company has faced in launching new brands and the disruption and expense associated with repositioning of its legacy brands; and the concern that as the company acquires brands that compete at better price points the increased fashion risk could introduce higher volatility to sales and profitability.

Kellwood's operating and credit metrics remain weak relative to its assigned rating category. Adjusted EBIT margin was $3.9 \%$ in fiscal 2005, excluding restructuring charges, down from $5.8 \%$ in the previous year. Moody's expects that operating profitability will return to between $5 \%$ and $7 \%$ in the near term. Leverage, as measured by adjusted debt / EBITDA is high at 7.0x and is likely to remain above $4.0 \mathrm{x}$ over the next two years. Liquidity, as measured by adjusted EBIT / interest expense is expected to improve from the $1.1 \mathrm{x}$ level posted in 2005 to over 3.0x by the end of the 2007 fiscal year. With the exception of fiscal 2004, Kellwood has historically generated good levels of free cash flow generation with adjusted FCF / debt standing at $27.9 \%$ at the end of fiscal 2005. 
The negative outlook reflects Moody's concern that the company's operating margin may remain below $5 \%$ for a prolonged period; the possibility that the relaunch of Calvin Klein and O Oscar may again fail to meet expectations; that the dress business may deteriorate at a faster than expected rate; and that Kellwood will continue to find its entry into the better women's sportswear market to be difficult.

\section{MCGRAW HILL COMPANIES INC - B\&G FOODS INC. UPGRADED TO 'B+' FROM 'B'}

\section{December 15, 2009- THE MCGRAW-HILL COMPANIES ("MHP-BHDNPX”) -} B\&G Foods Inc. completed an equity offering of class A common shares on Sept. 24, 2009 , raising about $\$ 86.9$ million of net proceeds, which were used on Nov. 2, 2009, to redeem $\$ 90$ million principal amount of its senior subordinated notes due 2016, resulting in lower debt leverage. We are raising the ratings, including the corporate credit rating to ' $\mathrm{B}+$ ' from ' $\mathrm{B}$,' and removing them from CreditWatch with positive implications. The outlook is stable, reflecting our expectation for stable operating performance and leverage remaining in the $4.5 \mathrm{x}$ area over the next year.

In addition, Standard \& Poor's raised the issue-level ratings on the company's senior secured credit facility to 'BB' from 'BB-' (two notches higher than the corporate credit rating). The recovery rating on this debt remains ' 1 ,' indicating our expectation for very high (90\%-100\%) recovery in the event of a payment default. We also raised the issue level ratings on the company's senior unsecured notes to ' $\mathrm{B}+$ ' from ' $\mathrm{B}$ ' (the same as the corporate credit rating), with a recovery rating of ' 4 ,' indicating our expectations for average recovery $(30 \%-50 \%)$ in the event of a payment default. Lastly, we raised the ratings on the company's senior subordinated notes to 'B-' from ' $\mathrm{CCC}+$ ' (two notches lower than the corporate credit rating), with a recovery rating of ' 6 ,' indicating our expectations for negligible $(0 \%-10 \%)$ recovery in the event of a payment default.

"The upgrade reflects our opinion that credit measures have improved following the company's equity issuance in September 2009," said Standard \& Poor's credit analyst Christopher Johnson. The transaction raised about $\$ 87$ million of net proceeds, which together with available cash was used to redeem $\$ 90$ million of the company's senior subordinated notes due 2016. We estimate that pro forma for the debt prepayment, leverage improved to about $4.5 \mathrm{x}$, compared with a ratio of $5.3 \mathrm{x}$ for the 12 months ended Sept. 30, 2009.

Analyst Contact: Christopher Johnson, CFA, New York (1) 212-438-1433.

\section{FITCH UPGRADES PS BUSINESS PARKS' IDR TO 'BBB+'; OUTLOOK STABLE}

April 21, 2011- Fitch Ratings has upgraded the credit ratings of PS Business Parks, Inc. (NYSE:PSB) and its operating partnership, PS Business Parks, L.P. (collectively, PS Business Parks or PSB) as follows:

PS Business Parks, Inc. -Issuer Default Rating (IDR) to 'BBB+' from 'BBB'; - $\$ 598.5$ million Preferred Stock to 'BBB' from 'BBB-'.

PS Business Parks, L.P. -IDR to 'BBB+' from 'BBB'; --\$100 million unsecured revolving credit facility to 'BBB+' from 'BBB.'

The Rating Outlook is Stable.

The upgrade of PSB's ratings reflects that the company is expected to generate a fixed charge coverage ratio that is commensurate with a ' $\mathrm{BBB}+$ ' rating. The upgrade 
also takes into account the company's minimal debt levels, which stem from a funding strategy focused on preferred and common stock and which result in low leverage and minimal refinance risk throughout capital market cycles. In addition, PSB's pool of unencumbered business parks provides value to unsecured creditors and preferred stockholders. While the company's credit ratings have been upgraded, Fitch's credit concerns for PSB include challenging commercial property market fundamentals in the company's modestly sized portfolio, as declining rental rates are expected to continue driving down same-park net operating income (NOI) in 2011. In addition, the company's near-term liquidity position has recently been adversely impacted by several transactions following a loan received from Public Storage.

Fitch Ratings | Primary Analyst | Sean Pattap, +1-212-908-0642 | Senior | Director | Fitch, Inc. | One State Street Plaza | New York, NY | 10,004 | or | Secondary Analyst | Steven Marks, +1-212-908-9161 | Managing | Director | or | Committee Chairperson | Nathan Flanders, | +1-212-908-0827 | Managing Director | or | Media Relations: Brian Bertsch, New | York, +1-212-908-0549 | brian.bertsch@ fitchratings.com | SOURCE: Fitch Ratings.

\section{Appendix 3}

Table 11 Variable definitions

\begin{tabular}{|c|c|c|}
\hline $\begin{array}{l}\text { Variable } \\
\text { Name }\end{array}$ & Description & Source \\
\hline Rating & $\begin{array}{l}\text { The rating of the issuer after the rating decision. Credit ratings } \\
\text { are measured over a } 22 \text {-point cardinal scale (e.g., } 1=\mathrm{AAA} \text {, } \\
2=\mathrm{AA}+\text {, and so on). }\end{array}$ & $\begin{array}{l}\text { Capital IQ - S\&P Credit Rat- } \\
\text { ings Database / Mergent }\end{array}$ \\
\hline Upgrade & $\begin{array}{l}\text { An indicator variable equal to one if the firm's rating is } \\
\text { upgraded and zero otherwise }\end{array}$ & $\begin{array}{l}\text { Capital IQ - S\&P Credit Rat- } \\
\text { ings Database / Mergent }\end{array}$ \\
\hline Fret & $\begin{array}{l}\text { The cumulative stock returns over the full period (i.e., }[-1950 \text {, } \\
\text { 120]) }\end{array}$ & TAQ \\
\hline LRet & $\begin{array}{l}\text { The cumulative stock returns over the leading period (i.e., } \\
[-1950,-781])\end{array}$ & TAQ \\
\hline PreRet & $\begin{array}{l}\text { The cumulative stock returns over the pre-announcement } \\
\text { period (i.e., }[-780,-2] \text { ) }\end{array}$ & TAQ \\
\hline AnnRet & $\begin{array}{l}\text { The cumulative stock returns over the announcement period } \\
\text { (i.e., }[-1,120])\end{array}$ & TAQ \\
\hline LWRet & $\begin{array}{l}\text { Cumulative stock returns between } 20 \text { and five trading days } \\
\text { before the announcement }\end{array}$ & CRSP \\
\hline CDS & $\begin{array}{l}\text { An indicator variable that is equal to one if the issuer has a } \\
\text { CDS contract available on its debt and zero otherwise }\end{array}$ & Bloomberg \\
\hline$\Delta \mathrm{CDS}$ Sppread & $\begin{array}{l}\text { The change in the five-year CDS spread between } 20 \text { and two } \\
\text { trading days before the announcement }\end{array}$ & Bloomberg \\
\hline Bond & $\begin{array}{l}\text { An indicator variable that is equal to one if at least one of the } \\
\text { issuer's bonds is actively traded between } 20 \text { and two trading } \\
\text { days before the announcement and zero otherwise }\end{array}$ & TRACE and Mergent \\
\hline
\end{tabular}


Table 11 (continued)

\begin{tabular}{lll}
\hline $\begin{array}{l}\text { Variable } \\
\text { Name }\end{array}$ & Description & Source \\
\hline BondRet & $\begin{array}{c}\text { Value-weighted cumulative return of all of the issuer's bonds } \\
\text { between } 20 \text { and two trading days before the announcement }\end{array}$ \\
MarketRet & $\begin{array}{l}\text { The value-weighted cumulative return of all firms in CRSP } \\
\text { over the three trading days ending with the day of the } \\
\text { announcement }\end{array}$ & CRSP \\
Abn_PreRet & $\begin{array}{c}\text { Three-digit SIC industry-adjusted cumulative stock returns } \\
\text { over the pre-announcement period (i.e., }[-780,-2])\end{array}$ & TAQ \\
Career_Path & $\begin{array}{c}\text { An indicator variable equal to one if the first position after the LinkedIn and Other Online } \\
\text { rating agency of at least one of the credit analysts named on } \\
\text { the rating report is with an asset/portfolio management firm }\end{array}$ & Sources \\
& $\quad$
\end{tabular}

\section{References}

Acharya, V., and T. Johnson. 2007. Insider trading in credit derivatives. Journal of Financial Economics 84 (1): $110-141$.

Agarwal, S., V. Chen, and W. Zhang. 2016. The information value of credit rating action reports: A textual analysis. Management Science 62 (8): 2218-2240.

Auh, J. 2015. Procyclical credit rating policy. Georgetown University. Working paper.

Beaver, W., C. Shakespeare, and M. Soliman. 2006. Differential properties in the ratings of certified versus non-certified bond-rating agencies. Journal of Accounting and Economics 42 (3): 303-334.

Beneish, M., E. Press, and M. Vargus. 2011. Insider trading and earnings management in distressed firms. Contemporary Accounting Research 29 (1): 191-220.

Boehmer, E., C. Jones, and X. Zhang. 2019. Tracking retail investor activity. Singapore Management University, Columbia Business School, and Tsinghua University. Working paper.

Bushman, R., A. Smith, and R. Wittenberg-Moerman. 2010. Price discovery and dissemination of private information by loan syndicate participants. Journal of Accounting Research 48 (5): 921-972.

Cantor, R., and C. Mann. 2006. Analyzing the tradeoff between ratings accuracy and stability. Journal of Fixed Income 16 (4): 60-68.

Chava, S., R. Ganduri, and C. Ornthanalai. 2012. Are credit ratings still relevant? Georgia Institute of Technology, Emory University, and University of Toronto. Working paper.

Cheng, M., and M. Neamtiu. 2009. An empirical analysis of changes in credit rating properties: Timeliness, accuracy and volatility. Journal of Accounting and Economics 47 (1-2): 108-130.

Christophe, S., M. Ferri, and J. Angel. 2004. Short-selling prior to earnings announcements. The Journal of Finance 59 (4): 1845-1876.

Christophe, S., M. Ferri, and J. Hsieh. 2010. Informed trading before analyst downgrades: Evidence from short sellers. Journal of Financial Economics 95 (1): 85-106.

Cornaggia, J., K. Cornaggia, and H. Xia. 2016. Revolving doors on Wall Street. Journal of Financial Economics 120 (2): 400-419.

Dechow, P., A. Lawrence, and J. Ryans. 2016. SEC comment letters and insider sales. The Accounting Review 91 (2): 401-439.

Eichenwald, K. 2004. Enron inquiry turns to sales by Lay's wife. The New York Times (November 17).

Even-Tov, O. 2017. When does the bond price reaction to earnings announcements predict future stock return? Journal of Accounting and Economics 64 (1): 167-182. 
Farrell, M., T. Grenn, R. Russell, and S. Markov. 2018. The democratization of investment research: Implications for retail investor profitability and firm liquidity. University of Kentucky, Emory University, and University of Taxes at Dallas. Working paper.

Forte, S., and J. Pena. 2009. Credit spreads: An empirical analysis on the informational content of stocks, bonds, and CDS. Journal of Banking and Finance 33 (11): 2013-2025.

Goh, J., and L. Ederington. 1993. Is a bond rating downgrade bad news, good news, or no news for stockholders? The Journal of Finance 48 (5): 2001-2008.

Goh, J., and L. Ederington. 1999. Cross-sectional variation in the stock market reaction to bond rating changes. The Quarterly Review of Economics and Finance 39 (1): 101-112.

Goldstein, M. 2004. Ex-S\&P Analyst and two others charged with insider trading. TheStreet.com, July 27.

Graham, J., R. Michaely, and M. Roberts. 2003. Do price discreteness and transactions costs affect stock returns? Comparing ex-dividend pricing before and after decimalization. The Journal of Finance 58 (6): 2611-2636.

Griffin, P., and A. Sanvicente. 1982. Common stock returns and rating changes: A methodological comparison. The Journal of Finance 37 (1): 103-119.

Griffin, J., and Y. Tang. 2011. Did credit rating agencies make unbiased assumptions on CDOs? American Economic Review 101 (3): 125-130.

Griffin, J., T. Shu, and S. Topaloglu. 2012. Examining the dark side of financial markets: Do institutions trade on information from investment bank connections? Review of Financial Studies 25 (7): 2155-2188.

Griffin, P., D. Lont, and K. Mcclune. 2014. Insightful insiders? Insider trading and stock return around debt covenant violation disclosures. Abacus 50 (2): 117-145.

Hand, J., R. Holthausen, and R. Leftwich. 1992. The effect of bond rating agency announcements on bond and stock prices. The Journal of Finance 47 (2): 733-752.

Holthausen, R., and R. Leftwich. 1986. The effect of bond rating changes on common stock prices. Journal of Financial Economics 17 (1): 57-89.

Hull, J., M. Predescu, and A. White. 2004. The relationship between credit default swap spreads, bond yields, and credit rating announcements. Journal of Banking and Finance 28 (11): 2789-2711.

Irvine, P., M. Lipson, and A. Puckett. 2007. Tipping. Review of Financial Studies 20 (3): 741-768.

Jiang, J., I. Wang, and K. Wang. 2018. Analysts and ratings of mortgage-backed and asset-backed securities: Evidence from Linkedin. Management Science 64 (12): 5832-5854.

Jorion, P., Z. Liu, and C. Shi. 2005. Informational effects of regulation FD: Evidence from rating agencies. Journal of Financial Economics 76 (2): 309-330.

Kempf, E. 2020. The job rating game: The effects of revolving doors on analyst incentives. Journal of Financial Economics 135 (1): 41-67.

Kempf, E., and M. Tsoutsoura. 2019. Partisan professionals: Evidence from credit rating analysts. University of Chicago and Cornell University. Working paper.

Kraft, P., Y. Xie, and L. Zhou. 2020. The timing of rating changes. Journal of Corporate Finance 60: 1-20.

Lattman, P. 2011. Fugitive Moody's analyst ordered to pay $\$ 35$ million to S.E.C. The New York Times, August 24.

Lee, C., and M. Ready. 1991. Inferring trade direction from intraday data. The Journal of Finance 46 (2): $733-$ 746.

May, A. 2010. The impact of bond rating changes on corporate bond prices: New evidence from the over-thecounter market. Journal of Banking and Finance 34 (11): 2822-2836.

Michaelides, A., A. Milidonis, G. Nishiotis, and P. Papakyriakou. 2015. The adverse effects of systematic leakage ahead of official sovereign debt rating announcements. Journal of Financial Economics 116 (3): 526-547.

Norden, L. 2017. Information in CDS spreads. Journal of Banking and Finance 75: 118-135.

Norden, L., and M. Weber. 2004. Informational efficiency of credit default swap and stock markets: The impact of credit rating announcements. Journal of Banking and Finance 28 (11): 2813-2843.

Norden, L., and M. Weber. 2009. The co-movement of credit default swap, bond and stock markets: An empirical analysis. European Financial Management 15 (3): 529-562.

Pinches, G., and J. Singleton. 1978. The adjustment of stock prices to bond rating changes. The Journal of Finance 33 (1): 29-44.

Securities and Exchange Commission. 2003. Report on the role and function of credit rating agencies in the operation of the securities markets. January. Washington, DC.

Securities and Exchange Commission. 2000. Final rule: Selective disclosure and insider trading. October 2010. Washington, DC.

Securities and Exchange Commission. 2011. Summary report of commission staff's examinations of each nationally recognized statistical rating organization. September. Washington, DC. 
Seyhun, H., and M. Bradley. 1997. Corporate bankruptcy and insider trading. The Journal of Business 70 (2): 189-216.

Stempel, J. 2018. U.S. charges S\&P analyst, 2 others with insider trading in paint merger. Reuters.com, June 26.

Von Beschwitz, B., D. Keim, and M. Massa. 2015. First to 'read' the news: News analytics and institutional trading. The Federal Reserve System, University of Pennsylvania, and INSEAD. Working paper.

Publisher's note Springer Nature remains neutral with regard to jurisdictional claims in published maps and institutional affiliations. 